\title{
Did the great influenza of 1918-1920 trigger a reversal of the first era of globalization?*
}

\author{
Pierre L. Siklos ${ }^{1,2,3}$
}

Accepted: 24 November 2021 / Published online: 22 January 2022

(c) The Author(s), under exclusive licence to Springer-Verlag GmbH Germany, part of Springer Nature 2021

\begin{abstract}
I revisit the 1918-20 pandemic and ask whether it led to a reversal in the rise of trade and financial globalization that preceded it. Using annual data for 17 countries for the 1870-1928 period, a variety of tests and techniques are used to draw some robust conclusions. Overall, the pandemic a century ago interrupted, but did not put an end, to the first globalization of the twentieth century. However, two blocs consisting of combatant and non-combatant countries, experienced significantly different consequences. Globalization was sharply curtailed for the combatant countries while there were few, if any, consequences for globalization in the non-combatant group of countries. That said, there was considerable resilience especially in trade openness among several of the combatant economies. Perhaps changes in the make-up of economic blocs, post-pandemic, is a fallout from shocks of this kind. While there are lessons for the ongoing COVID pandemics differences between the 1920s and today also play a role.
\end{abstract}

Keywords Great Influenza 1918-20 · Globalization · Openness · Financial integration

JEL Classification $\mathrm{N} 10 \cdot \mathrm{O} 57 \cdot \mathrm{F} 15 \cdot \mathrm{F} 36$

Pierre L. Siklos

psiklos@wlu.ca

1 Wilfrid Laurier University, Waterloo, ON, Canada

2 Balsillie School of International Affairs, Waterloo, ON, Canada

3 Centre for Applied Macroeconomi Analysis (CAMA), Australian National University, Canberra, Australia 
"The projects and politics of militarism and imperialism, which were to play the serpent to this paradise, ....appeared to exercise almost no influence at all...” John Maynard Keynes (1919, p. 10)

“..., one finds surprisingly little concern about the possible ill effects of the influenza on the economy, perhaps because the more dominant narrative concerned the impact of World War I,..." Robert Shiller (2020)

\section{Introduction}

Twice in the past decade alarms have been raised warning us that the forces of globalization might be reversed. The Great Financial Crisis of 2008-9 (GFC) was expected to reduce the openness of economies around the globe. While the near financial meltdown in the second half of 2008 would produce a sharp fall in global trade (e.g., see Baldwin 2009) the slump would prove to be temporary. Despite worries in some quarters about a return to 'beggar-thy-neighbour' policies, perhaps in the form of 'currency wars' (e.g., see Blanchard 2017), the eventual reaction of central banks, and a determination on the part of the authorities to improve financial regulation and supervision, no doubt contributed to forestalling a reversal of the forces that favor greater financial globalization.

Second, the pandemic of 2020 generated interruptions in global supply chains and renewed worries over the stability of the global financial system. The emergence of COVID at a time when populism is seen to be on the rise, fueled perhaps by globalization (e.g., see Rodrik 2020a) has also raised the prospect that a reversal in global trade may eventually take hold. Early indications based on widely used indicators such as Swiss Economic Institute's Globalisation Index (Gygli et al. 2019; Dreher 2006), ${ }^{1}$ reveal a bending of the curve since an acceleration of trade and financial globalization beginning in the 1990s. However, there is no evidence of a reversal as this is written.

It is too soon, of course, to declare that globalization will be reversed, this time due to the COVID-19 pandemic, but it is natural to ask whether there are lessons from an earlier period of globalization. Over a century ago, a sequence of events apparently heralded the end of an earlier era of rapid trade and financial integration. That period, sometimes referred to as the first era of globalization, has been studied previously (e.g., see Bordo et al. 2010). Soon after the first era of globalization is believed to have peaked, around the eve of World War I, the global economy would suffer the consequences of the Great Influenza that began at war's end in 1918 and lasted until 1920.

Not surprisingly, the current pandemic has rekindled interest in the topic of globalization, especially in trade which is seen as more vulnerable to interruptions due to health motivated restrictions on the transportation of goods. As a result, some

\footnotetext{
1 The index is updated monthly. See https://kof.ethz.ch/en/forecasts-and-indicators/indicators/kof-globa lisation-index.html.
} 
have pointed to the potential risks of a looming de-globalization linked to the current pandemics (e.g., Antràs et al. 2020). Whether and how the current episode of globalization differs from the experience of the 1930s remains unsettled, but many factors were at play (e.g., see Tooze 2014; Accominotti and Eichengreen 2016; Bordo et al. 1999; O'Rourke 2019).

Globalization, of course, is also reflected in the evolution of the financial system. Finance operates largely electronically and is more immune to interruptions of the kind triggered by a global virus. This is true now and, as telegraph usage spread and travel became much speedier a century ago, was also a feature of economic life during the first decade of the twentieth century. Today, the combined impact of looser monetary and fiscal policies worldwide is also leading some to worry about rapidly rising levels of sovereign debt. No comparable response can be detected in response to the Great Influenza of 1918-20 though the global conflict that preceded it impacted debt levels. ${ }^{2}$

Unlike today, when granular data are more readily available allowing for a precise and methodical analysis of the eventual consequences of the COVID-19 virus, data limitations are more severe when the consequences of the pandemic of the early twentieth century are considered. ${ }^{3}$ That said, there is some micro level evidence from that time for a few countries that documents how large was the health shock arising from the Great Influenza of 1918-2910 with a range of economic consequences ranging from the short-lived to well over a decade (e.g., Karlsson et al. 2014; Velde 2020; Guimbeau et al. 2020).

Interest in the economic consequences of the Great Influenza has recently been rekindled. Nevertheless, as far as I am aware, no one has explored quantitatively how, or if, trade and financial globalization were impacted by the earlier global pandemic. Indeed, several retrospectives about the globalization phenomenon do not explicitly mention the 1918-1920 pandemic (e.g., Baldwin and Martin 1999; Bordo et al. 1999; Schularick and Steger 2006; Rodrik 2020b). Other events, notably the negotiations over the Versailles Treaty following the end of World War I, play a much larger role in retrospectives of the time though not all of these mention the Great Influenza (e.g., Macmillan 2001) in spite of the fact that all of the main characters in Paris at the time, including Keynes, would catch the flu. Indeed, the "...conference became a vector for contagion." (Carter 2020, p. 64). ${ }^{4}$

\footnotetext{
2 This episode is also often referred to as the 'Spanish Flu', but the precise origins of the pandemic remain in dispute. In addition, there are significant variations in estimates of the total number of deaths. Estimates range widely (e.g., Spreeuwenberg et. al. (2018) estimates 17.4 million, Barro et al. (2020) gives a figure of 39 million, Burdekin (2021) mentions a figure of at least 50 million, and Jordà et al., 2020, Table 1, give a figure of 100 million). The lack of precision in mortality estimates for the 19181920 pandemic is well-known in the epidemiology literature. See, for example, Ansant et al. (2009).

${ }^{3}$ Indeed, the workhorse Susceptible-Infected-Recovered (SIR) model of pandemics of Kermack and McKendrick (1927) was introduced well after the pandemic ended. See Avery et al. (2020) for more details.

${ }^{4}$ Keynes (1932, p. 5) would later describe the mood in the following terms: "Paris was a nightmare, and everyone there was morbid.".
} 
Briefly, I find that the state of globalization was quite heterogeneous in 17 advanced and emerging markets considered in this study. To be sure, integration of goods and financial markets was on the upswing beginning the last decades of the nineteenth century, but it was uneven across countries. More importantly, the economic impact of the 1918-1920 pandemic appears to be sensitive according to whether a country was among the combatants in World War I. In terms of globalization the countries directly implicated in the war suffered most from the potential gains from greater openness in trade and financial integration. And yet, the setback to globalization in several, but not all, countries examined in this study was only temporarily. It is difficult to find scarring effects, at least at the macroeconomic level, as a result of the Great Influenza.

To be sure, then as now, the benefits and costs of globalization continue to be debated and it will always remain problematic to identify pandemic related economic effects from the economic consequences of World War I. Moreover, while David Hume may have been one of the first to argue that "...kingdom that has a large import and export, must abound more with industry..." (Copley and Edgar 1993, p. 162) not everyone is convinced that globalization in any of its forms is economically beneficial for all concerned. However, globalization nowadays is merely the latest with several precedents reflecting the fact that "...globalizations are cumulative, but also subject to crises and reversals" (Darwin 2020, p. xivQuery).

Of course, it can be perilous to draw too many lessons for the most recent pandemic. There are important asymmetries between conditions at the beginning of the twentieth century and the first two decades of the twenty-first century. Nevertheless, it is striking that, despite a global economic depression during the 1930s followed by a second world war, globalization in trade and, eventually finance including a return to freer capital mobility, would resume quickly after the end of the Great Influenza. Indeed, although the first globalization was eventually reversed for a time during the 1930s, the impact of the 1918-1920 pandemic appears to have been transitory. Given the differences between conditions a century ago and today this cannot be taken as a prediction for what to expect on the other side of the COVID-19 crisis. Hence, de-globalization is not a foregone conclusion.

We should also not lose sight of the parallels between the early twentieth century and today. Keynes, in preparing readers for his critique of the Versailles Treaty, pointed out that "[T]he inhabitant of London could order by telephone, sipping his morning tea in bed, the various products of the whole earth...[H]e could secure forthwith ...cheap and comfortable means of transit to any country..." (Keynes 1919, p. 10). Similarly, while we refer nowadays to global supply chains, at the time World War I began, it was noted that "dependence of manufactures on an even larger number of raw material inputs...demanded a 'planetary' economy." (Darwin 2020, p. 341) Finally, it appears that the same countervailing forces pushing back against globalization today were also at play back in the early 1900s. "Politics in recent years has erected walls that restrict all these movements." (Staley 1971, p. 51). ${ }^{5}$

\footnotetext{
5 The reference to movements applied to goods, capital, and knowledge. Staley's work was originally published in 1939.
} 
The rest of the paper is organized as follows. The next section briefly reviews the economics literature dealing with the 1918-1920 influenza. Given that previous research dealing with various facets of the globalization phenomenon is vast I limit attention to a few select references. Readers will be able to explore the broader literature from these sources. Section 3 introduces the data, and some summary indicators are discussed, prior to conducting an econometric analysis. The focus of the exercise, supported by existing economic theory, is on the impact of the 1918-1920 pandemic on openness and financial integration, conditional on inflation and several other controls, including the impact of World War I, the Gold Standard, and political factors. The resort to annual data, the relative brevity of the period when influenza raged around the globe, and some uncertainty surrounding the precision of estimates of mortality and combat deaths to name two factors, argue for relying on a menu of techniques to ensure some robustness and reliability in the econometric estimates obtained. Section 4 concludes.

\section{Related literature}

Economic histories of the first globalization and of the economic consequences of the growth of trade and financial globalization at the end of the $19^{\text {th }}$ and early twentieth centuries tend to avoid mentioning the Great Influenza (e.g., see Bordo et al. 2010; O'Rourke 2019). Even The Economist (2020), looking back at the share of articles that mention the Spanish flu, finds that the topic is dwarfed by a large margin by other events such as wars, the Great Depression, and several other keywords. Perhaps this partially explains narratives, as noted by Shiller (2020) at the beginning of the paper, that appear to downplay a significant role for this event despite the large number of deaths that accompanied it. Another reason, as detailed in Darwin (2020), is the combined impact of mass movement by steamship and railway spread any disease quickly. ${ }^{6}$ The nineteenth century is replete with a string of epidemics and pandemics (e.g., see Baldwin, 1999). The Great Influenza would prove to be just one more in a series of communicable diseases some of which would spread throughout the world (e.g., see Candela and Geloso 2021). Many were short-lived in economic history terms and any economic analysis likely pushed aside because other, longer lasting events such as wars, attracted relatively more interest. The Great Influenza is distinct from the others because it was a truly global event.

Instead, economic historians have placed greater emphasis on the Gold Standard, or the political upheavals in the global economy at the time. However, it is precisely this kind of focus that draws attention to asymmetries between the two waves of globalization that define a good deal of twentieth century economic history. As a result, several studies focus on economic factors during the 1870-1913 period in part avoiding the period of World War I and the subsequent pandemic. In principle, this period represents the zenith in the purest form of the Gold Standard

\footnotetext{
${ }^{6}$ Indeed, Darwin (2020) calls the period under investigation in this study the era of "steam globalization".
} 
though research over time reveals a volatile period economically with sudden stops in capital movements impacting emerging market economies of the time (e.g., see Bordo et al. 2010; Accominotti and Eichengreen 2016) and attempts at certain forms of protectionism to stimulate economic activity (e.g., see Schularick and Solomou 2011). The bottom line is that, beyond the adoption of a comparable exchange rate regime across many countries, considerable heterogeneity remained. The Gold Standard, which represented economic normalcy, exerted such a powerful force that a resumption was to take place in most of the countries considered in this study. Indeed, in some countries (e.g., Japan), the Gold Standard was eventually seen as the conduit through which global trade would rise quickly (e.g., see Mitchener et al. 2010). Nevertheless, this did not prevent some (viz., France, Italy), after World War I, to choose stabilization via inflation and devaluation over deflation (viz., UK, and US; e.g., see Eichengreen 1992; Ahamed 2009; and Tooze 2014). All these developments have echoes in the most recent wave of globalization of recent decades.

According to the usual metrics of trade intensity or openness, the latter defined as export and imports as a proportion of GDP, and financial integration, broadly characterized by the free movement of capital or the convergence of interest rates, the period before World War I especially appears to have all the signs of an era where considerable globalization was achieved. This is also reflected in the opening quote from Keynes (1919).

Crafts and Venables (2003); Neal and Weidenmeier (2003); Obstfeld and Taylor (2003); Baldwin and Martin (1999); Bordo et al. (1999); and Schularick and Steger (2006) are some examples of studies that have considered, either descriptively, or via empirical evidence, the evolution of trade and financial integration typically prior to World War I. Despite a consensus of sorts that globalization was the dominant economic force during this period it is also the case that its evolution did not appear to be particularly linear in nature. ${ }^{7}$ The relatively free movement of goods and capital prior to World War I especially suggests a similarity with what became known as the Washington Consensus of the 1980s.

Once we dig deeper, however, this is where the similarities with globalization of recent decades end. Advanced economies in early twentieth century were far less industrialized than they are today (Bairoch, 1982). Social welfare programs of the kind that exist in the countries in the data set considered in this paper were also far less developed. Moreover, the widespread adoption of the Gold Standard in the pre-Great Depression of the 1930s is a significant departure from the range of exchange rate regimes in place in advanced economies today generally favoring a floating exchange rate combined with policies aimed at achieving a certain inflation objective. In contrast, the Gold Standard aimed at price level control. Indeed, the Gold Standard arguably provides an early example of the potential globalization

\footnotetext{
7 For example, Obstfeld and Taylor (2003, Fig. 3.1) provide a highly stylized view of capital mobility showing it rising quickly from 1860, reaching a peak on the eve of World War I only to drop suddenly recovering only modestly during the inter-war era. Trading patterns would also change following World War I as the United States began its ascendancy to become the dominant global power at the expense of Great Britain.
} 
of inflation. Consequently, the incidence of deflation was considerably higher and persisted during the era considered in this paper. ${ }^{8}$ That said, actual adherence to the Gold Standard could be quite distant from the textbook model (e.g., Flandreau and Zumer (2004), and references therein). Notwithstanding the adoption of more flexible exchange rates in recent decades the global element in inflation has not been far from the minds of policy makers. Nevertheless, the connection between the Gold Standard, and the globalization that began during the second half of the nineteenth century, is still mentioned as holding lessons for today. In particular, the Gold Standard is seen as a clear rule (also see Bordo and Kydland 1995) and, together with a role for certain norms, these represent important ingredients that can encourage the development and rise of globalization (e.g., see Rodrik 2020b).

Beyond the realm of economic policy there are other similarities and differences between the two waves of globalization. As has been true over the past thirty years or so, technological change and the costs of transportation and communication fell sharply over time beginning the late nineteenth century. Indeed, writing prior to the start of World War II, Staley (1971) argued that technological change was the driving force of globalization, or integration as it was called then, in trade and finance. As a result, accounts of US economic and financial history around this time (e.g., Quinn and Turner 2020, chapter 7; Gordon 2017; Field 2011) would subsequently characterize the decade of the 1920s and 1930s as arguably among the most productive in history. Perhaps partly for this reason the decade of the 1920 s deserves its appellation as the "Roaring Twenties". The era also cemented, at least until World War I, the pre-eminence of London in trade and finance (e.g., Michie 1992). Of course, the boom in the decade after the Great Influenza would end in tears as a result of the Great Depression. ${ }^{9}$

In the political realm, the period between 1870 and 1928 would be far more volatile than the world has experienced during the last few decades (e.g., see Tooze 2014). Whereas, at least until very recently, trends have favoured more democracy and less political instability, conditions were far more volatile during the era of the first globalization. ${ }^{10}$ Finally, a World War with large numbers of casualties also threatened globalization whereas the last few decades, while not free of conflagrations, have been relatively more peaceful. Political factors likely also play an

\footnotetext{
8 The Appendix provides a table with the quantitative details. Perhaps in part for this reason, it is difficult to reject the stationarity of inflation during this era though possibly with one or more breaks (see below). The connection between deflation and economic activity during the late $19^{\text {th }}$ until World War II is the subject of extensive research along several dimensions. See, for example, Burdekin and Siklos (2004).

9 The appendix contains a Table comparing real GDP growth for the 1901-13, 1922-28, and 1930-38 periods. In 15 of 17 countries considered, growth is higher post-pandemic than pre-World War I and is lower in the 1930s, often sharply, in 16 of 17 countries. Japan is the exception for reasons explained in Shizume (2009).

10 Polity V data used in the empirical estimates to be discussed below confirms this. Obstfeld and Taylor (2003) also draw from an earlier version of this data set to argue for an increase in political openness in the decade that followed the end of World War I. A Table in the Appendix lists changes in polity levels and in levels of executive authority during the sample considered in this paper relative to levels attained in 2018 .
} 
important role since there is a vast literature that draws a direct link from democratic institutions to globalization, even if the precise direction of causality remains in dispute (e.g., see Eichengreen and Leblang (2008), and references therein).

The eruption of a global conflict presents a potential difficulty for an econometric analysis of economic developments during the period under investigation unless it is viewed as an exogenous event. For example, Ferguson (2020) makes the case, based on public statements before 1914, and other sources, that World War I came as a "bolt from the blue". O'Rourke (2019) lists arguments and provides references to a literature that argues against this interpretation. To be sure, World War I exacerbated the severity of the Great Influenza, but the virus spread globally even in countries that were not directly implicated in the conflict. Moreover, while it is tempting to assume that the pandemic is uniquely associated with the battlefields of World War I, this is far from the consensus. For example, Humphries (2012) finds that the Great Influenza's emergence in Canada, a participant in World War I but not one of the battleground countries, was not traced to the war. Barry (2004) also leaves some doubts about the direct association between the war and the Great Influenza. It is worth noting that, while armed conflicts and pandemics generate large numbers of casualties, the former also destroys productive capacity while pandemics do not. Indeed, depending on the fallout from a pandemic, subsequent infrastructure may well be improved. Of course, a pandemic of the scale of the Great Influenza is a large negative labour supply shocks with negative economic consequences whether or not a war precedes it. However, while armed conflict is easily seen as facilitating a de-globalization, it is not evident this result holds for the effects of a pandemic.

As noted previously, the latest pandemic has led some to revisit the economic impact of the Great Influenza. In what follows I restrict attention to cross-country research. Readers, of course, can consult several country-specific studies (e.g., Barro (2020), Velde (2020), Garrett (2007), Bishop (2020), and references therein). Barro et al. (2020), relying on annual data for 43 countries, report that, globally, the 1918-1920 pandemic produced an economic contraction ranging between 6 to $8 \%$ which is comparable to the decline experienced in the most recent global financial crisis. Geloso and Murtavashvili (2020), and Geloso and Pavlik (2021) have argued, given that historical data from that period has often had to be constructed or reconstructed, that Barro's results change if a different historical data set is used (viz., Maddison's Historical Statistics ${ }^{11}$ ). Burdekin $(2020,2021)$, using monthly instead of annual data, finds that the Great Influenza significantly and negatively impacted stock returns in a sample of 10 countries and notes that the sampling frequency of the data can play a role in estimates of the economic effects of a pandemic of the Great Influenza variety. ${ }^{12} \mathrm{~A}$ wider range of negative economic growth outcomes from the 1918-1920 pandemic is reported in De Santis and Van der Vehen (2020).

\footnotetext{
11 https://www.rug.nl/ggdc/historicaldevelopment/maddison/releases/maddison-project-database-2020.

12 When deaths from the flu are examined at the monthly frequency a spike in late 1918 (especially in October and November), they dwarf casualties at other times during the pandemic. See, for example, Karlsson et. al. (2014) for Sweden, Guimbeau et. al. (2020), for Brazil, Burdekin (2021) for several countries, and, more generally, Barry (2004).
} 
Others, such as Jordà et al. (2020), and Ma et al. (2020), have produced empirical evidence on the impact from several pandemics across history in a panel setting. Setting aside whether the heterogeneity of the viruses leading to pandemics over time is adequately controlled for or even informative, these studies conclude that such short-lived events can scar economies for decades while producing a negative economic shock that rivals the fallout from banking type financial crises.

Overall, while there is some evidence of the negative macroeconomic effects of the Great Influenza of 1918-1920, much less is known about its consequences for trade and financial globalization. Keeping in mind Schularick and Solomou's (2011) warning that the period which preceded the first pandemic of the twentieth century reveals a complex relationship between economic activity and openness due, in part, to the heterogeneity of the countries affected, I turn to some empirical evidence.

\section{Data, Theoretical and econometric frameworks}

Annual data for the period 1870-1928 are used. As noted above, the decade of the 1930s follows the Great Depression of 1929 and it is likely that the long-term effects of the pandemic of 1918-20 would be overtaken by other events that are difficult to associate with the Great Influenza. Moreover, controlling for the differential impact of the policies enacted following the stock market crash of 1929 would unnecessarily complicate the analysis and, in any case, there is a general consensus that the 1930s is a period of de-globalization as well as an altogether separate era (O'Rourke (2019), Tooze (2014), Staley (1971), and references therein).

Almost all the series employed were obtained from the Jordà-Schularick-Taylor Macrohistory database ${ }^{13}$ which consists of data for 17 economies since 1870 . As noted earlier there exist differences across available historical data sets but the Jordà-Schularick-Taylor data have been widely used and are easily obtained. This also facilitates replication. Five of the countries in question, namely the UK, France, Germany, the Netherlands, and Switzerland, would have been called the advanced economies of the era while the remainder would be labelled emerging by presentday standards or 'periphery' economies. They are: Australia, Canada, Belgium, Italy, Japan, Portugal, the US, Denmark, Finland, Norway, Spain, and Sweden. For the purposes of this study the more relevant distinction is between combatant and non-combatant countries. Ten of 17 countries contributed troops resulting in combat deaths. Combatant countries are: Australia, Canada, Belgium, France, Italy, Japan, Portugal (by 1916), the UK, and the USA (by 2017).

Data on combat deaths and deaths from the 1918-1920 pandemic are from Barro et al. (2020). The reader is reminded that existing estimates are subject to

\footnotetext{
13 These can be downloaded from http://www.macrohistory.net/data/. It should be noted that for Japan, the long-term interest rate data are from the London market and not Tokyo. There are a few differences (see the appendix) for a few years before World War I and after the pandemic, but these do not appear to be large enough to overturn the results shown below. For Japan's experience during this era see Mitchener et al. (2010).
} 
error. That said, Barro's pandemic period data has been used by others and are also readily available. A few additional series were obtained from Marshall and Gurr's (2020) Polity V database which contains data on the political regimes and the degree of power held by the executive branch of government. ${ }^{14}$ I also relied on some data from Mitchell (1992) to complement the aggregate trade data used to construct a trade openness series. Finally, as is true nowadays, given the possibility that trading patterns, capital flows and, therefore, openness can be impacted by tariffs and other trade restrictions, as well as limits placed on capital mobility, I also use the annual data of relevant indexes constructed by Prados de la Escosura (2016). These are indicators based on the Fraser Institute's Economic Freedom rankings. ${ }^{15}$

Romer (1993) is credited with the idea that trade openness and inflation are negatively linked. ${ }^{16}$ Theoretical arguments suggest that this kind of relationship holds for all types of countries and exchange rate regimes except possibly for the most highly developed economies that are able to overcome Kydland and Prescott's (1977) dynamic inconsistency problem. Neither the possibility that openness and inflation may be endogenously related to each other nor that other institutional factors (e.g., central bank independence, political factors) may also help explain openness affect the negative inflation-openness link.

Not surprisingly, Romer's hypothesis generated a considerable literature which, subsequently, yielded mixed results. For example, Terra (1998) notes that Romer's findings were driven by the responses of severely indebted countries during the debt crisis of the 1980s. Wynne and Kersting (2007) also revisit Romer's hypothesis and point out that the slope of the Phillips curve may play a role and one that is at odds with the predictions of the negative openness-inflation link. Nevertheless, the principal hypothesis is not overturned but other factors, such as labor and capital mobility, are also at play. Cooke (2010) questions the negative openness-inflation link on the grounds that the terms of trade also play a role. Despite doubts raised about the precise sources of the relationship between openness and inflation that link serves as a useful starting point for investigating the impact of a pandemic on openness. Moreover, inflation as one of the drivers of globalization in trade also provides a connection to explain changes in financial integration over time.

The free flow of capital ought to facilitate the narrowing of interest rate differentials across countries. This is especially true in the textbook version of the Gold Standard. Moreover, the advent of the telegraph greatly facilitated the

\footnotetext{
14 The data are available from https://www.systemicpeace.org/inscrdata.html. The data are normalized in a range from 0 to 10 . The tariff index is defined such that higher tariffs translate into a higher value for the index; in the case of trade restrictions, a lower index means greater trade restrictions; for capital mobility a lower index value translates into less capital mobility. The appendix plots each one of these indicators for the sample in the paper. A summary table that gives means values of the various indices for various samples is also relegated to the appendix.

15 https://www.fraserinstitute.org/economic-freedom/map?geozone=world\&page=map\&year=2018.

16 Romer (1993) defines openness as imports to GDP but the subsequent literature has generally adopted the convention that openness is exports and imports to GDP. I retain the current definition of openness.
} 
movement of credit thereby also helping level interest rates across the world. Indeed, if investors are focused on real returns, this gives rise to the Obstfeld and Taylor (2003) argument that real returns ought to be stationary or that crosscountry dispersion of yields should decrease. Nevertheless, it is worth pointing out that several metrics have been used to evaluate the degree of financial integration. Therefore, the specifications discussed below control for the degree of capital mobility.

Since, according to the Fisher equation, nominal interest rates are determined by inflation (more precisely, inflation expectations), inflation is the core variable that is associated with the state of integration or globalization. Accordingly, the most basic formulations to be tested can be written as follows:

$$
\begin{gathered}
\omega_{i t}=\alpha_{i}+\lambda_{t}+\gamma_{i} \pi_{i t}+\beta_{i} \delta_{i t}+\theta_{i} \boldsymbol{X}_{i t}+\varnothing_{i} \omega_{i, t-1}+\varepsilon_{i t} \\
\rho_{i t}=\alpha_{i}^{*}+\lambda_{t}^{*}+\gamma_{i}^{*} \eta_{i t}+\beta_{i}^{*} \delta_{i t}+\theta_{i}^{*} Z_{i t}+\varnothing_{i}^{*} \rho_{i, t-1}+\varepsilon_{i t}^{*}
\end{gathered}
$$

where $\omega$ and $\rho$ are, respectively, openness and the real interest rate. The former is the sum of nominal exports and imports as a percent of nominal GDP. The real interest rate is the long-term interest rate less current inflation. ${ }^{17}$ The subscripts $i$ and $t$ identify the country in question and time, in years. The first two terms to the right of the equality are country and time fixed effects, while $\pi$ and $\eta$ are, respectively, inflation and money growth. The relationship between inflation and openness is the one derived by Romer (1993). In the textbook model of the Gold Standard if, say, bank rate in London rises to check inflation then, other things equal, this draws gold from elsewhere which implies a reduction in the money supply. The Jordà-Schularick-Taylor database has both a narrow (i.e., currency and demand deposits) and a broader measure of the money supply (i.e., narrow money supply plus certain bank deposits). The conclusions discussed below are unchanged for either money supply measure. However, since a broader monetary aggregate is not available for Belgium, some of the results below use the narrow money supply series.

The focus of the analysis is on the coefficients $\beta$ and $\beta^{*}$. These capture the impact of deaths $(\delta)$ from the pandemic. I use the death rates, converted to per 1000 of population from Barro et al. (2020). Finally, the vectors $\boldsymbol{X}$ and $\boldsymbol{Z}$ capture other potential cross-country determinants of openness and the real interest rate. These include the number of combat deaths, again per 1000 of population, also

\footnotetext{
17 There are no data on inflation expectations during the period (a point also made by Accominotti and Eichengreen 2016). It is not uncommon to resort to the definition used here (e.g., see Bordo and Siklos 2016) though others, such as using lagged inflation, year ahead inflation, or a blend of the two, were also considered. While conclusions are largely unchanged when using alternative measures of inflation, the size of estimated coefficients of interest (see below) can be affected. Unfortunately, theory offers little guide about how best to estimate real interest rates during this era. Also note that, in the case of Germany, I follow Romer (1993) and use the logarithm of inflation post-pandemic given the hyperinflation of $1921-23$.
} 
obtained from Barro et al. (2020), dummy variables for financial crises and the Gold Standard, real GDP growth, the debt to GDP ratio, as well as the interaction between the polity or executive authority and death rates from the pandemic or combat. Other than deaths from the Influenza or the World War I dummy the remaining variables are lagged one period. To conserve space, however, $\boldsymbol{X}$ and $\boldsymbol{Z}$ are shown as contemporaneously related to the dependent variables. In order to capture the persistence in openness and the real interest rate, both dependent variables are lagged one period. Finally, since openness is also influenced by administrative or institutional restrictions due to tariffs, and other limitations on the movement of goods and capital, I also add controls using the indexes developed by Prados de la Escosura (2016) discussed earlier.

One final comment is in order. The specifications (1) and (2) are written in this manner because I am interested in the impact of the pandemic on openness and financial integration. Clearly, as noted earlier, the nexus between inflation and openness in Eq. (1), or money growth and the real interest rate in Eq. (2) can conceivably be bi-directional. Although some experimentation with instrumental variable estimation did not change the conclusions (results not shown) such an exercise does detract from the focus of the paper. In addition, the period in question raises considerable difficulties in finding useful instruments beyond the usual lags in the right-hand side variables. To allay some fears about the potential endogeneity of some of the right-hand side variables alternative methodologies are also considered below.

While Eqs. (1) and (2) can capture the impact of deaths from the pandemic the coefficients themselves provide average responses to the specified determinants. Given the heterogeneity in the evolution of globalization over time (see also below) it is not immediately clear whether the impact of deaths need be the same for countries which are relatively more open than others.

Dealing with cross-country heterogeneity of the kind just mentioned can be accommodated by re-writing (1) and (2) such that estimates are conditioned on quantiles. That is, the dependent variables respectively become $\omega_{i t, \tau}$ and $\rho_{i t, \tau}$ where $\tau$ refer to quantiles. This approach moves us away from a focus on mean responses alone toward estimating the impact of the Great Influenza where openness was high (or low) relative to the mean of the distribution of openness across the 17 countries in the sample.

It is equally of interest to ascertain the longer-term implications of pandemic, not to mention the endogeneity issue raised above. Hence, I also use the local projections method (Jordà, 2005) to investigate the impact of a shock to $\delta$ in Eqs. (1) and (2) on openness and real interest rates. The response of these two variables to deaths from the pandemic can be written as follows:

$$
\begin{gathered}
\omega_{i, t+h}=\tau_{i}^{h}+\beta_{i}^{h} \delta_{i t}+\sum_{k=1}^{K} \varphi_{i}^{h} \omega_{t-k}+\theta_{i} X_{i t}+\varepsilon_{t+h}^{h} \\
\rho_{i, t+h}=\tau_{i}^{* h}+\beta_{i}^{* h} \delta_{i t}+\sum_{k-1}^{K} \varphi_{i}^{* h} \rho_{t-k}+\theta_{i}^{*} Z_{i t}+\varepsilon_{t+h}^{h}
\end{gathered}
$$


All the terms were previously defined, $h=1, \ldots, H$ is the time horizon over which the local projections are estimated, and $\mathrm{k}$ is set to 1 . I set $H=10$ so that the impulse responses, that is, estimates of $\beta$ and $\beta^{*}$ are traced out over a 10 year ahead period.

Finally, as the question being considered is whether a regime of trade or financial integration can be overturned, I also consider the case where there are two states of the world, namely high versus low globalization regimes. In these circumstances, it seems natural to estimate a Markov switching model. In order to estimate more precisely the evolution of probability estimates for remaining in the highly integrated regime for each economy in the sample I estimate individual country Markov switching models. Hence, the dependent variables in (1) and (2) become $\omega_{t, s}$ and $\rho_{t, s}$ where $s=1,2$ to capture openness and the real interest rate in two states. Note also that the $i$ subscript is dropped.

\section{Empirical Evidence}

Figure 1 plot the time series for trade openness for the sample used in this study, namely 1870-1928. The shaded areas identify World War I (1914-18) and the period of the Great Influenza (1918-20). Where this happens during the sample considered, thick vertical dashed lines indicate whether a central bank was created during the sample. ${ }^{18}$ A positive trend in openness, at least until the outbreak of World War I is clearly visible in several cases, such as for Belgium, Italy, Japan, Denmark, the Netherlands, and Norway. Rates at which openness rose in these countries varies, of course. However, in several other cases, notably the UK, France, the USA, and Switzerland, there is no noticeable upward trend to speak of. Indeed, a comparison of trends since post-World War II (see the appendix) suggests that the rise in openness was considerably more impressive in the last few decades. Looking at the period after World War I begins considerably greater volatility is observed. This should not be surprising since all the economies under investigation have some trading relationship. ${ }^{19}$ In addition, while there are visible signs of a speedy recovery in several countries such as the UK, Japan, Portugal, Denmark, and Finland, there are also more than a few examples of substantial declines in openness. Canada, the USA, the Netherlands, Sweden, and Switzerland serve as illustrations of this phenomenon.

Table 1 provides some summary statistics for both openness and the real longterm interest rate $(\rho)$. In the latter case I also provide summary statistics for both the full sample and pre-World War I period. Full sample mean values for $\rho$ are always lower than for the pre-war era. However, pre-World War I, there seems to be more evidence of convergence in real interest rates than for the full sample. Indeed, the changes that took place once war erupts are large. Of course, we observe the large

\footnotetext{
18 Other than Canada and Australia, all the remaining countries had central banks before 1870 .

19 A Table in the appendix gives each country's top three trading partners. The UK and Germany are one of the top exporters or importers for all the other countries in the sample. France and the USA are next in line.
} 
UK
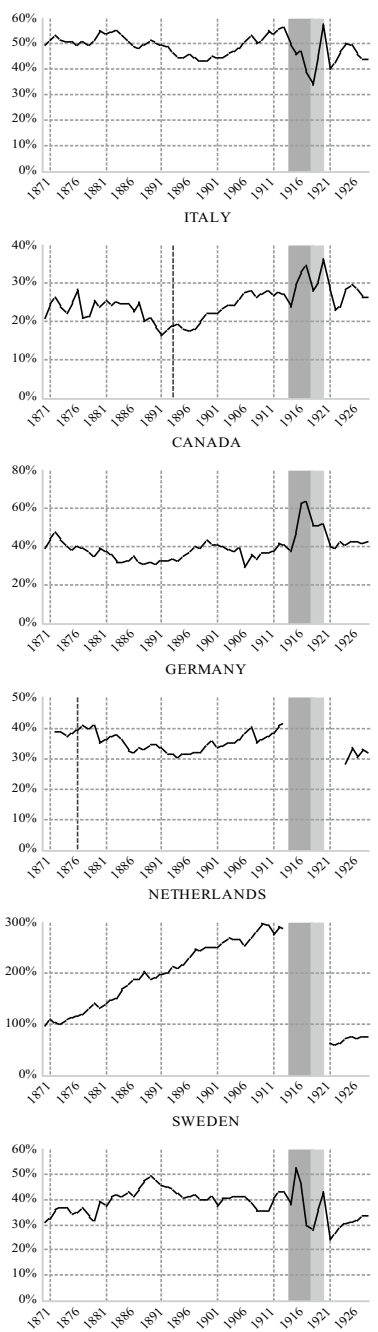

FRANCE

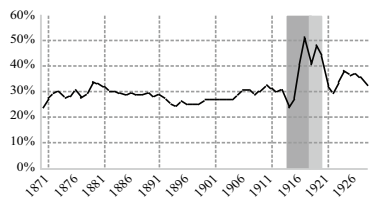

JAPAN
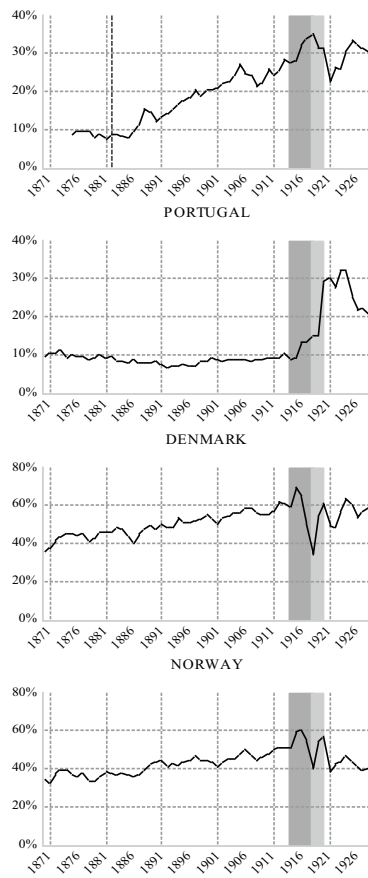

SWITZERLAND

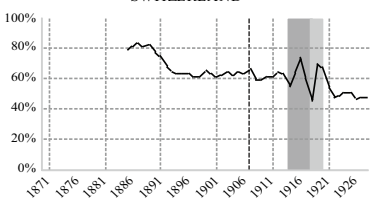

BELGIUM
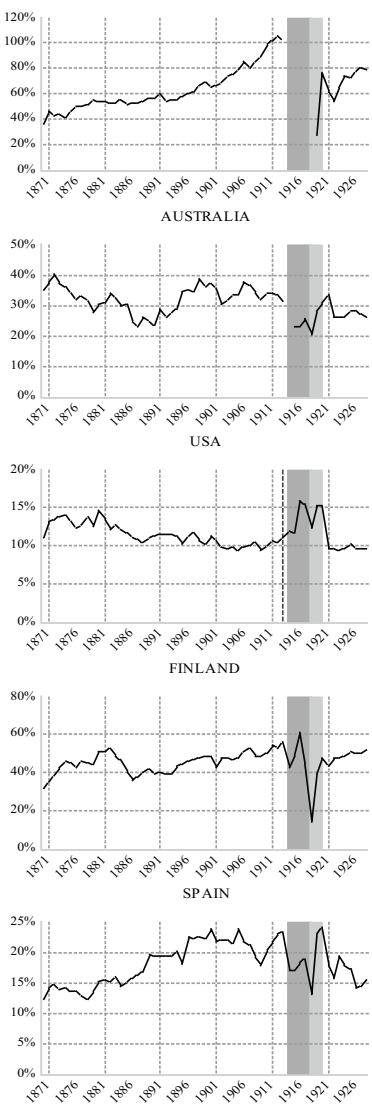

Fig. 1 Openness: 1870-1928. Note: Openness is 100 times (Exports + Imports)/GDP. Data from http:// www.macrohistory.net/data/. The 1914-18 and 1918-20 periods are highlighted as are, where appropriate, years when central banks were introduced. Gaps in the lines indicate data are not available

negative real returns in Germany due to the 1921-23 hyperinflation. Moreover, while the distribution of returns is excessively skewed to the right in a few cases (Canada, Italy) the combined effects of the war, the pandemic, and the period thereafter results in the distribution of real returns becoming excessively negatively skewed in several cases (Finland, France, Germany, Italy, Portugal, Sweden, and the UK). All these countries, except Sweden, were combatants in World War I. Neither Fig. 1 nor Table 1 point to any obvious differences between combatant and non-combatants countries. However, there is clearly considerable cross-country heterogeneity in the 
Table 1 Openness and Real Long-Term Interest Rates: Summary Statistics

\begin{tabular}{|c|c|c|c|c|c|c|}
\hline \multirow[t]{3}{*}{ Country } & \multirow{2}{*}{\multicolumn{2}{|c|}{$\frac{\text { Openness }}{1870-1928}$}} & \multicolumn{4}{|c|}{ Real interest rate } \\
\hline & & & \multicolumn{2}{|c|}{$1870-1928$} & \multicolumn{2}{|c|}{ 1870-1913 } \\
\hline & Mean & Skewness & Mean & Skewness & Mean & Skewness \\
\hline AUS & 30.82 & -0.12 & 3.30 & -0.02 & 3.43 & -0.44 \\
\hline BEL & 63.51 & 0.62 & 1.99 & -0.57 & 3.14 & -0.004 \\
\hline CAN & 39.35 & 1.48 & 2.86 & 0.28 & 3.11 & 1.08 \\
\hline DNK & 51.11 & -0.004 & 3.27 & 0.09 & 3.90 & 0.07 \\
\hline FIN & 45.34 & -1.62 & 0.51 & -4.66 & 4.03 & 0.22 \\
\hline FRA & 30.64 & 1.83 & 0.83 & -1.78 & 3.38 & -0.009 \\
\hline DEU & 35.20 & 0.17 & -4.79 & -5.38 & 3.19 & 0.38 \\
\hline ITA & 24.59 & 0.33 & 0.780 .7 & -1.86 & 5.18 & 1.90 \\
\hline JPN & 20.30 & -0.04 & 3.52 & 0.05 & 3.93 & 0.81 \\
\hline NED & 180.75 & -0.08 & 3.08 & 0.13 & 3.38 & 0.42 \\
\hline NOR & 42.95 & 0.76 & 2.98 & -0.91 & 3.41 & 0.37 \\
\hline PRT & 11.76 & 1.95 & 1.78 & -1.79 & 6.64 & -0.82 \\
\hline ESP & 18.04 & 0.08 & 6.43 & -0.86 & 8.33 & 0.76 \\
\hline SWE & 38.33 & -0.20 & 2.97 & -1.27 & 3.50 & 0.44 \\
\hline $\mathrm{CHE}$ & 63.03 & 0.21 & 3.18 & -0.23 & 3.77 & 0.96 \\
\hline GBR & 48.78 & -0.55 & 2.14 & -1 & 2.73 & 0.02 \\
\hline USA & 11.49 & 0.83 & 3.40 & -0.88 & 4.41 & 0.95 \\
\hline
\end{tabular}

See Fig. 1 for data source and openness definition. The real interest rate is the nominal long-term interest rate less current CPI inflation. Values in italics indicate excess positive or negative skewness

openness and real interest rate record. As we shall see below, however, some asymmetries emerge from the econometric estimates. ${ }^{20}$

The first set of econometric estimates are shown in Table 2. Panel versions estimates of Eqs. (1) and (2) are shown. Three sets of estimates for each equation were generated. One version includes all 17 countries for which we have data while separate estimates for countries where there were combatants and deaths from the pandemic were recorded and ones where only deaths from the pandemic are relevant. It should be noted that other variants, not shown, were also estimated to ascertain the sensitivity of the results to the omission of Germany (and others) from the sample as all the other combatant countries were allied. I also examined cases where Portugal (1916) and the USA (1917) are omitted as they entered late in the war, as

\footnotetext{
${ }^{20}$ It may be worth noting that a series of tests asking whether, in a panel setting, openness and real interest rates are cointegrated cannot reject the null of no cointegration. This result holds for both the 1870-1928 and 1870-1913 samples. These test results are not conditioned on the possibility of structural breaks in the series. Separate tests find at least one break in the individual country openness or real interest rate series. When the sample is 1870-1928 breaks possibly associated with the pandemic are found for only three countries (Belgium, Netherlands and Norway). When the 1870-1913 sample is concerned, most breaks in both series are found in 1879-1892 period, that is, a period of considerable financial instability. Test details are available on request.
} 
Table 2 Panel Estimates: Determinants of Openness and Financial Integration

\begin{tabular}{|c|c|c|c|c|c|c|}
\hline \multirow[t]{2}{*}{ Variables } & \multicolumn{3}{|l|}{ Openness $(\omega)$} & \multicolumn{3}{|c|}{ Real Interest Rates $(\rho)$} \\
\hline & All countries & Combatants & $\begin{array}{l}\text { Non-combat- } \\
\text { ants }\end{array}$ & All countries & Combatants & $\begin{array}{l}\text { Non-combat- } \\
\text { ants }\end{array}$ \\
\hline Deaths & $\begin{array}{l}-0.70 \\
(0.14)^{*}\end{array}$ & $\begin{array}{l}-0.83 \\
(0.11)^{*}\end{array}$ & $\begin{array}{l}-0.34 \\
(0.55)\end{array}$ & $\begin{array}{l}-1.37 \\
(0.41)^{*}\end{array}$ & $\begin{array}{l}-1.31 \\
(0.45)^{*}\end{array}$ & $\begin{array}{l}-1.40 \\
(1.44)\end{array}$ \\
\hline Combat & $\begin{array}{l}3.51 \\
(1.80) \#\end{array}$ & $\begin{array}{l}2.69 \\
(1.99)\end{array}$ & NA & $\begin{array}{l}-7.76 \\
(2.43)^{*}\end{array}$ & $\begin{array}{l}-8.11 \\
(2.04)^{*}\end{array}$ & NA \\
\hline Death*Polity & $\begin{array}{l}0.03 \\
(0.02) \#\end{array}$ & $\begin{array}{l}0.03 \\
(0.01)^{* *}\end{array}$ & $\begin{array}{l}-0.12 \\
(0.07) \#\end{array}$ & $\begin{array}{l}-0.12 \\
(0.03)^{*}\end{array}$ & $\begin{array}{l}-0.13 \\
(0.03)^{*}\end{array}$ & $\begin{array}{l}-0.13 \\
(0.19)\end{array}$ \\
\hline Combat*Exec & $\begin{array}{l}-0.66 \\
(0.31)^{* *}\end{array}$ & $\begin{array}{l}-0.61 \\
(0.34) \#\end{array}$ & NA & $\begin{array}{l}1.09 \\
(0.40)^{*}\end{array}$ & $\begin{array}{l}1.01 \\
(0.37)^{*}\end{array}$ & NA \\
\hline Inflation & $\begin{array}{l}0.12 \\
(0.04)^{*}\end{array}$ & $\begin{array}{l}0.16 \\
(0.05)^{*}\end{array}$ & $\begin{array}{l}0.18 \\
(0.13)\end{array}$ & NA & NA & NA \\
\hline $\begin{array}{l}\text { Inflation* } \\
\text { Gold Std }\end{array}$ & $\begin{array}{l}-0.08 \\
(0.04) \#\end{array}$ & $\begin{array}{l}-0.12 \\
(0.05)^{*}\end{array}$ & $\begin{array}{l}-0.33 \\
(0.15)^{* *}\end{array}$ & NA & NA & NA \\
\hline$\omega(-1)$ & $\begin{array}{l}0.93 \\
(0.02)^{*}\end{array}$ & $\begin{array}{l}0.90 \\
(0.04)^{*}\end{array}$ & $\begin{array}{l}0.98 \\
(0.02)^{*}\end{array}$ & $\begin{array}{l}-0.02 \\
(0.01)\end{array}$ & $\begin{array}{l}-0.02 \\
(0.10)\end{array}$ & $\begin{array}{l}-0.01 \\
(0.01)\end{array}$ \\
\hline Fin. Crisis(-1) & $\begin{array}{l}-1.16 \\
(0.38)^{*}\end{array}$ & $\begin{array}{l}-1.20 \\
(0.58)^{* * *}\end{array}$ & $\begin{array}{l}-0.82 \\
(1.50)\end{array}$ & $\begin{array}{l}1.23 \\
(0.95)\end{array}$ & $\begin{array}{l}0.25 \\
(1.25)\end{array}$ & $\begin{array}{l}4.96 \\
(1.42)^{*}\end{array}$ \\
\hline Spread(-1) & $\begin{array}{l}-0.06 \\
(0.06)\end{array}$ & $\begin{array}{l}-0.04 \\
(0.08)\end{array}$ & $\begin{array}{l}-0.54 \\
(0.53)\end{array}$ & NA & NA & NA \\
\hline Gold Std & $\begin{array}{l}0.08 \\
(0.34)\end{array}$ & $\begin{array}{l}0.41 \\
(0.49)\end{array}$ & $\begin{array}{l}-0.15 \\
(1.61)\end{array}$ & $\begin{array}{l}-3.39 \\
(1.15)^{*}\end{array}$ & $\begin{array}{l}-2.23 \\
(1.09)^{* *}\end{array}$ & $\begin{array}{l}-5.49 \\
(1.37)^{*}\end{array}$ \\
\hline Debt/GDP(-1) & $\begin{array}{l}0.46 \\
(0.59)\end{array}$ & $\begin{array}{l}1.13 \\
(0.94)\end{array}$ & $\begin{array}{l}2.59 \\
(3.72)\end{array}$ & $\begin{array}{l}-2.22 \\
(1.22) \#\end{array}$ & $\begin{array}{l}0.52 \\
(0.97)\end{array}$ & $\begin{array}{l}-3.41 \\
(2.93)\end{array}$ \\
\hline Real GDP(-1) & $\begin{array}{l}-0.01 \\
(0.03)\end{array}$ & $\begin{array}{l}-0.03 \\
(0.03)\end{array}$ & $\begin{array}{l}-0.12 \\
(0.19)\end{array}$ & $\begin{array}{l}-0.19 \\
(0.09)^{* *}\end{array}$ & $\begin{array}{l}-0.07 \\
(0.11)\end{array}$ & $\begin{array}{l}-0.24 \\
(0.09)^{*}\end{array}$ \\
\hline WWI & $\begin{array}{l}-2.40 \\
(1.24)\end{array}$ & $\begin{array}{l}0.42 \\
(1.84)\end{array}$ & $\begin{array}{l}-9.03 \\
(4.65) \#\end{array}$ & $\begin{array}{l}-5.37 \\
(3.46)\end{array}$ & $\begin{array}{l}-1.33 \\
(2.15)\end{array}$ & $\begin{array}{l}-11.50 \\
(1.60)^{*}\end{array}$ \\
\hline$\rho(-1)$ & NA & NA & NA & $\begin{array}{l}0.08 \\
(0.11)\end{array}$ & $\begin{array}{l}0.14 \\
(0.09)\end{array}$ & $\begin{array}{l}0.004 \\
(0.05)\end{array}$ \\
\hline $\begin{array}{l}\text { Money } \\
\text { Growth(-1) }\end{array}$ & NA & NA & NA & $\begin{array}{l}-0.22 \\
(0.05)^{*}\end{array}$ & $\begin{array}{l}-0.34 \\
(0.14)^{* *}\end{array}$ & $\begin{array}{l}-0.05 \\
(0.06)\end{array}$ \\
\hline Tariffs & $\begin{array}{l}5.44 \\
(2.23)^{* *}\end{array}$ & $\begin{array}{l}3.16 \\
(2.67)\end{array}$ & $\begin{array}{l}8.72 \\
(10.99)\end{array}$ & $\begin{array}{l}-6.84 \\
(5.11)\end{array}$ & $\begin{array}{l}-6.83 \\
(4.10) \#\end{array}$ & $\begin{array}{l}-15.05 \\
(4.14)^{*}\end{array}$ \\
\hline Trade & $\begin{array}{l}-9.49 \\
(3.61)^{*}\end{array}$ & $\begin{array}{l}-4.25 \\
(5.04)\end{array}$ & $\begin{array}{l}-19.79 \\
(16.78)\end{array}$ & $\begin{array}{l}7.98 \\
(10.30)\end{array}$ & $\begin{array}{l}10.34 \\
(6.94)\end{array}$ & $\begin{array}{l}21.33 \\
(6.96)\end{array}$ \\
\hline Cap. Mob & $\begin{array}{l}5.13 \\
(1.90)^{*}\end{array}$ & $\begin{array}{l}2.37 \\
(2.63)\end{array}$ & $\begin{array}{l}10.40 \\
(9.02)\end{array}$ & $\begin{array}{l}-4.29 \\
(5.48)\end{array}$ & $\begin{array}{l}-5.47 \\
(3.69)\end{array}$ & $\begin{array}{l}-11.66 \\
(3.78)\end{array}$ \\
\hline $\mathrm{R}^{2}$ & 0.98 & 0.97 & 0.99 & 0.47 & 0.52 & 0.53 \\
\hline Fixed Effects & YES & YES & YES & YES & YES & YES \\
\hline $\begin{array}{l}\text { No. Cross sec- } \\
\text { tions }\end{array}$ & 17 & 10 & 7 & 17 & 10 & 7 \\
\hline Obs & 772 & 490 & 282 & 764 & 482 & 282 \\
\hline
\end{tabular}

panel least squares estimates, with heteroskedasticity adjusted (White) period cluster standard errors. Sample, before any differencing is 1870-1928. Some money supply data are missing for early years for some combatant countries so narrow monetary aggregate used; otherwise, a broad money aggregate definition is used. The SPREAD is the domestic vis-a-vis the UK long-term interest rate as the benchmark. Data sources are given in the main body of the text. Exec is the degree of executive authority in government and the Polity variable is the state of democracy. Details are provided in the text 
well as versions where equations for the advanced economies versus the emerging market economies of the time are estimated separately. None of the conclusions are affected. ${ }^{21}$ Only the combatant versus non-combatant cases consistently and robustly generates the asymmetries discussed below. ${ }^{22}$

Consider first the determinants of openness. When all countries are included, one cannot reject the null that openness and inflation are positively related. This is contrary to Romer's hypothesis but, as noted above, it is unclear why this would hold under a textbook version of the Gold Standard regime where shocks are transmitted directly to other economies. A rise in combat related deaths increases openness and this is not offset by the interaction of combat deaths and countries where the executive has greater power to impose policies on the public. In contrast, a 1000 more deaths from the pandemic reduces openness by $0.65 \%$ on average but this is offset slightly the more democratic the polity. Overall, the pandemic only modestly reduced trade integration over the sample.

When the analysis turns to estimates for combatants versus non-combatants significant differences emerge. First, in the case of combatant countries, the opennessinflation link remains positive. Although a dummy variable for whether a country adhered to the Gold Standard is also included it was pointed out earlier that effective commitment to that regime was variable. It is worth noting, however, that the group of combatant countries were relatively closer to adhering to the textbook version of the pegged regime than the remaining countries in the data set. Indeed, when the panel regressions include only the non-combatants, the openness-inflation link turns negative, consistent with Romer (1993), although the coefficient is not statistically significant. While more deaths from the pandemic reduces openness among the combatant countries, as before, there is no longer any statistical connection between combat deaths and trade integration. Indeed, the combined impact of combat deaths and the interaction between these casualties and executive authority is also no longer statistically significant. Next, more democratic polities, combined with deaths from the pandemic, now generate less not more openness as was previously reported. Instead, it appears that the positive link between deaths from the pandemic and the quality of the polity is a feature of combatant countries. When non-combatants are considered (third column) the openness-inflation relationship turns insignificant.

Two final differences between the results for combatants and non-combatants are worth noting. A financial crisis is associated with a fall in trade integration for the combatant countries, reflecting the fact (also see below) that these same countries

\footnotetext{
21 Another potential combination would exclude Finland as well as Germany. Finland entered the war on the Allied side as the Grand Duchy of Finland, a state in Russia's empire, but would end the war on the German side. There was considerable unrest as World War I raged, leading to a large number of deaths, which ended with Finland's independence in 1917. This may partly explain the sharp drop in openness around this time (see Fig. 1). Once again, the conclusions are unchanged, and some relevant estimates are also relegated to the appendix.

22 Another consideration as noted above, especially in the case of the openness equation, is whether estimates are impacted by the possibility of a unit root in $\omega$ (also see footnote 20). Where appropriate Eq. (1) was re-estimated in first differences. None of the conclusions discussed below are changed. The same problem does not arise in the case of Eq. (2).
} 
Fig. 2 A. Impact of Pandemic Death Rates on Openness: Quantile Estimates. Note: Eq. (1) estimated for the quantile range shown. Epanechnikov kernel sparsity, Hall-Sheather bandwidth method, and Huber sandwich standard errors. B. Impact of Pandemic Death Rates on Real Interest Rates: Quantile Estimates. Note: Eq. (2) estimates for the quantile range shown. See also note to Fig. 2A for additional details

were also more financially integrated. The same link is no longer statistically significant for the non-combatant group of countries. Indeed, it is wartime that sees the largest negative impact on trade globalization. The coefficient is several times larger than any of the other statistically significant coefficients. However, the impact is primarily restricted to the non-combatant economies with no significant impact seen for the group of combatants.

Turning to the equation of the determinants of financial integration one can observe many parallels in the kinds of asymmetries found for openness. Hence, 1000 deaths from the pandemic are found to reduce real long-term interest rates by well over $1 \%$ on average. If we also include the impact of the interaction of polity and pandemic deaths the reduction in real rates is just over 1.5\%. Combat deaths have over five times as large a negative effect on real long-term interest rates as does the pandemic. In contrast, for the non-combatant countries, there is no statistically significant impact from the Great Influenza. Combat deaths have a considerably larger negative impact in both combatant and non-combatant countries. However, it is the entire World War I period that generates the largest negative impact on real interest rates in countries not directly implicated in the conflict. No such effect is significant for the combatant group of countries.

Examining some of the remaining control variables, money growth impacts real interest rates in combatant countries, as expected since these adhered more closely to the Gold Standard. However, whereas financial crises raise significantly real rates in non-combatant countries no such effect is detected in the countries implicated in the war. It is worth noting that, other than the Netherlands and Switzerland, all the remaining countries can be considered as being in the periphery of the conflict. Overall, we observe how World War I and the pandemic, together with the role of the country in question, depressed real interest rates and created significant divergences that were less apparent pre-World War I.

It is worth noting that the indicators of tariffs, trade and capital flow restrictions (i.e., tariff, trade, cmob) are generally insignificant except for the panel for openness that combines all countries (column 1). Hence, these variables have relatively little bearing on the nexus between openness and the other variables in the regressions. Omitting them does not impact the conclusions reported above. Higher tariffs raise openness although this is more than offset by the negative impact of greater trade restrictions on openness. ${ }^{23}$ Similarly, only the panel that estimates the determinants of financial integration in the group of non-combatant economies sees tariffs, trade and capital mobility restrictions significantly impacting real interest rates. Higher tariffs are seen as lifting real interest rates for the non-combatants, as do greater trade restrictions, while greater capital mobility reduces the real interest rate.

\footnotetext{
23 A Wald test that the sum of tariffs and trade coefficients is zero is rejected (F-stat $=5.83$ $(\mathrm{p}$-value $=0.02)$ ).
} 


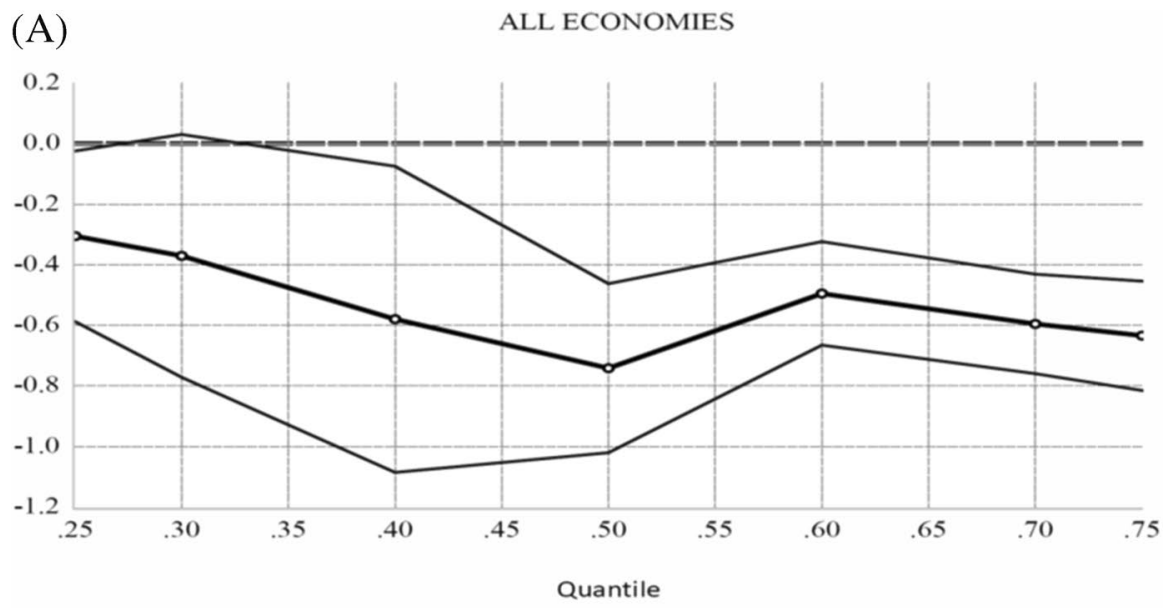

ALL COMBATTANTS

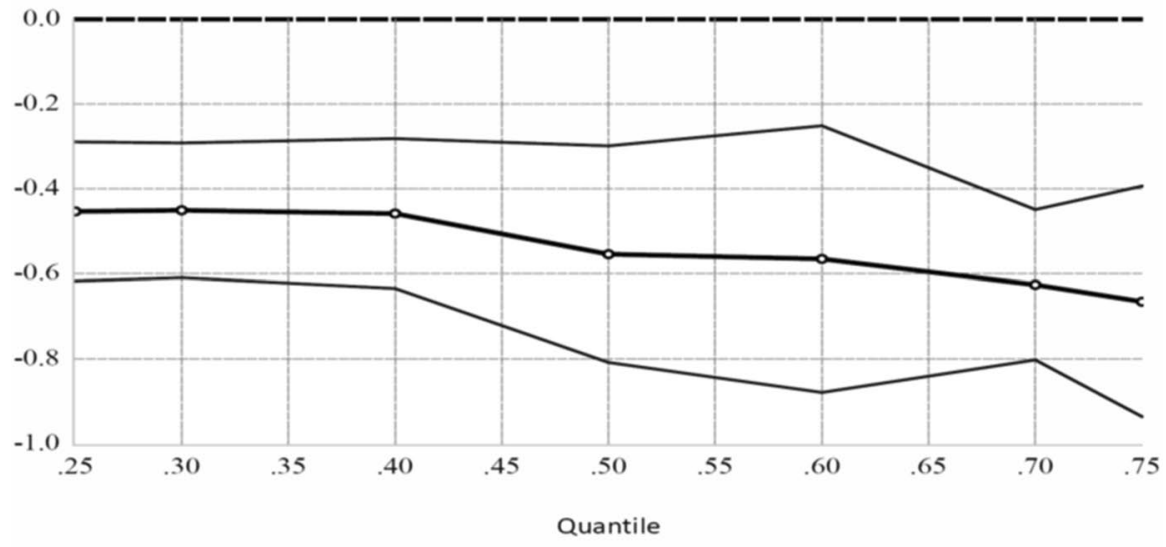

ALL NON-COMBATTANTS

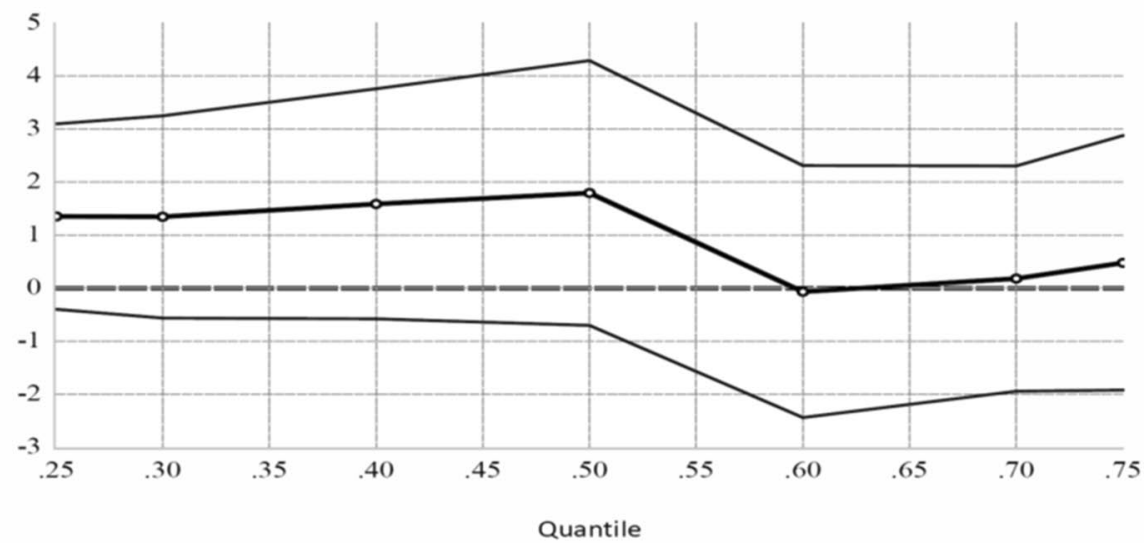


(B)

ALL ECONOMIES

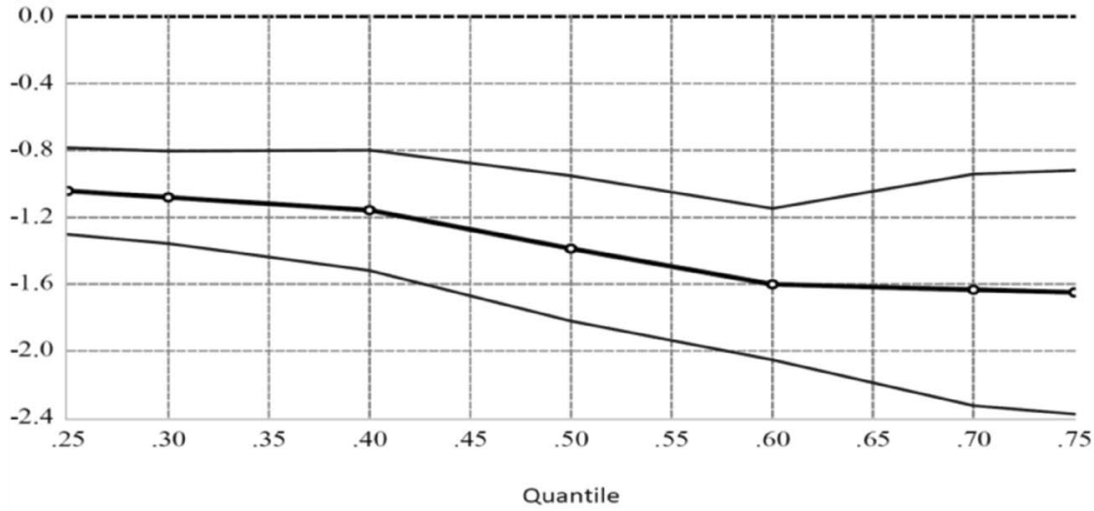

ALL COMBATTANTS

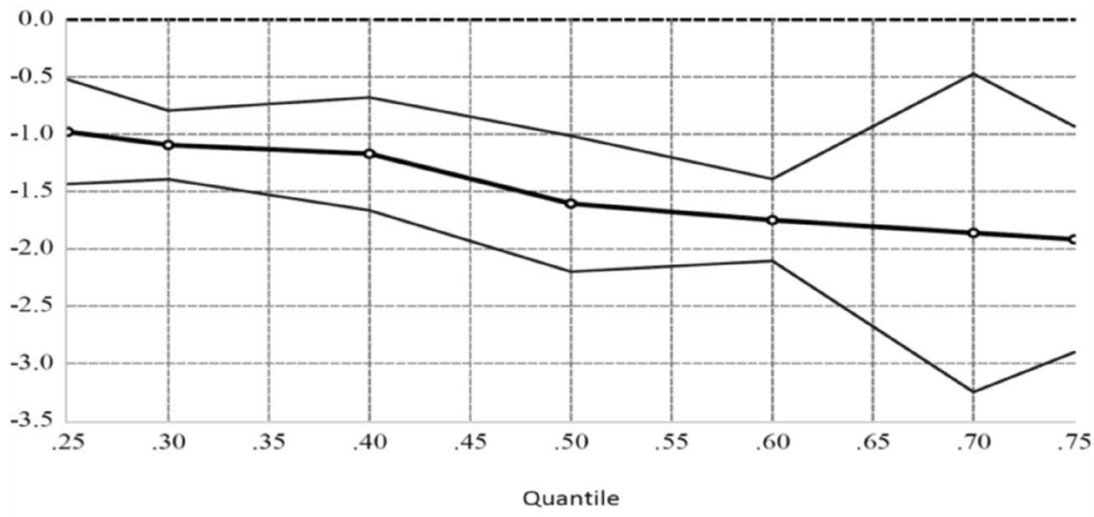

ALL NON-COMBATTANTS

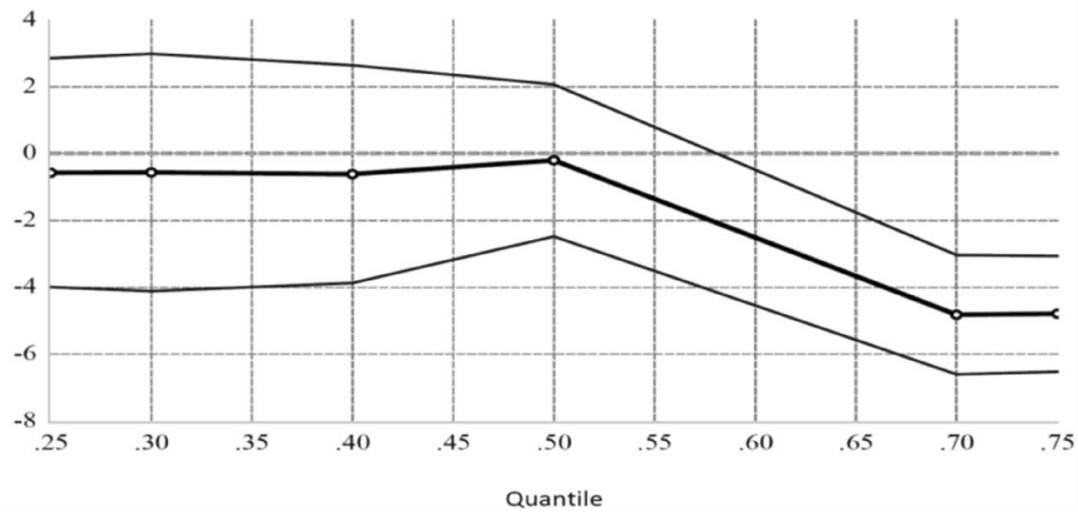

Fig. 2 (continued) 
Previously it was noted that there is considerable heterogeneity in levels of integration. Hence, a focus on the mean in the distribution of rates of globalization worldwide may produce misleading results. Accordingly, versions of Eqs. (1) and (2) were also estimated for a range of quantiles. Since the focus of this study is on the impact of the pandemic on globalization Figs. 2A and B plot the estimated coefficient on $\delta$ over a wide range of quantiles. In the case of openness, the asymmetry noted in the panel estimates is once again apparent based on the panel quantile regressions. Thus, the reduction in trade openness is concentrated in the group of combatant countries. None of the quantiles of estimates of the impact of $\delta$ are statistically significant for the non-combatants. The reduction in real interest rates due to the Great Influenza is larger for those countries that are relatively open (i.e., the right tail of the distribution of openness). It is also seen that, while the average response is negative and economically large but insignificant (see Table 2), the effect becomes statistically significant among countries that are highly integrated (e.g., the Netherlands; also see Table 1).

Next, we consider the degree to which the pandemic, as a shock, impacts the future course of openness and financial integration. For this, I turn to local projections. Estimates for the coefficient of deaths from the pandemic (i.e., $\beta$ or $\beta^{*}$ ). Figures $3 \mathrm{~A}$ and $\mathrm{B}$ display the impulse responses. When all economies are considered together there appears to be no lasting impact on openness and only a transitory and negative effect on real interest rates. When the impulse responses for combatant and non-combatants are estimated separately the reduction in openness is small but still significant even after 10 years, at least when the \pm 1 SD confidence intervals are considered. Nevertheless, the cumulative impact remains modest. For real interest rates there is an impact effect (i.e., at lag 0) but it does not persist. And, consistent with earlier findings (see Table 2), none of the impulse response are significant even if the \pm 1 SD confidence bounds are considered.

Two more statistical exercise are considered in assessing the impact of the 1918-20 pandemic on globalization. Figures 4A and B provide selected estimates of the probabilities of being in the 'high' globalization state based on a two-regime Markov switching model estimated for each individual country in the sample. Because the data are at the annual frequency the models estimated are simplified versions of Eqs. (1) where the openness-inflation or real interest rate- money growth relationships are allowed to vary by state, but the impact of death rates and combat deaths is assumed to be common to both states. In recognition of the central role of the UK economy in globalization at the time the estimates are also conditioned on the level of UK openness lagged one period. The selected results accurately portray the overall impact of World War I and the pandemic on the state of globalization. Thus, for example, in Fig. 4A, five of the eight cases shown suggest a shift into the 'low' globalization state after 1920 (Germany, the Netherlands, Portugal and Switzerland) while Japan shifts to the high globalization state soon after it introduces the silver standard in $1886 .{ }^{24}$ Since not all of these economies are directly implicated in World War I but no doubt are impacted by events in the region, this does

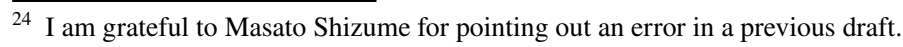


Fig. 3 A. Impulse Responses of the Impact of Pandemic Death Rates on Openness. Note: Eq. (1) estimated via the local projections method. See Eq. (3). The black lines are the mean coefficient estimates and the two bands are, respectively, + or -1 or 2 standard deviations around the mean. B. Impulse Responses of the Impact of Pandemic Death Rates on Real Interest Rates. Note: See note to Fig. 3A. Estimates are for Eq. (4)

suggest that the pandemic, on top of the conflict of 1914-18, had a negative impact on globalization levels that were, typically, much higher, especially prior to 1914 . Nevertheless, it is interesting to note that Australia, Canada, the UK, and the US go against this trend. All were, of course, directly implicated but these countries did not incur physical damage unlike, say, France.

Next, if we examine the probability of being in a 'high' financial integration state (Fig. 4B), we observe, for example, how the degree of financial integration can be episodic as in the case of Norway and Sweden. Both countries are linked together economically more tightly perhaps than are several of the other countries in the data set. Both adhered to the Gold Standard (until 1917 for Norway and 1914 for Sweden) and, while Sweden rejoined in 1922, Norway did not. Nevertheless, both moved into the low financial integration state during the 1920s. The role of the UK as driving the degree of financial integration is also seen even through the war despite dropping out of the Gold Standard only to rejoin in 1925. Portugal and Finland rejoin the financial integration state following a brief departure during the war and the pandemic. Once Norway leaves the Gold Standard altogether the probability of remaining in the financially integrated state falls to zero. Nevertheless, there is relatively little overall impact on the state of financial integration due to the war or the pandemic per se but the 1920s does see notable shifts towards or away from financial integration. Finally, in its interesting to note the rising levels of the likelihood of being in the financially integrated state for the USA beginning with its entry into combat in World War I. As many historians and economic historians have noted, the 1920s represents the decade when the USA begins to replace the UK as the dominant global financial and economic power.

The final test consists in conducting a counterfactual experiment. Suppose we estimate models (1) and (2) in their original panel format for the period 1870-1913 and generate out of sample forecasts for the remainder of the sample. The resulting model estimates would omit the impact of World War I and the pandemic. Recall that although the war and the pandemic both produce casualties the former also destroys infrastructure and, therefore, physical productive capacity. Moreover, as it is fairly clear that the drivers of openness and real interest rates differ as between combatant and non-combatant countries, these are the only forecasts considered. ${ }^{25}$ Figure 5 displays the out of sample forecasts and outturns for openness while Table 3 presents some summary statistics for real interest rate forecasts as a graphical representation is far less informative for the financial integration proxy.

\footnotetext{
25 In any case, forecasts for all countries were also generated and these confirm the earlier asymmetries found between combatant and non-combatant countries.
} 


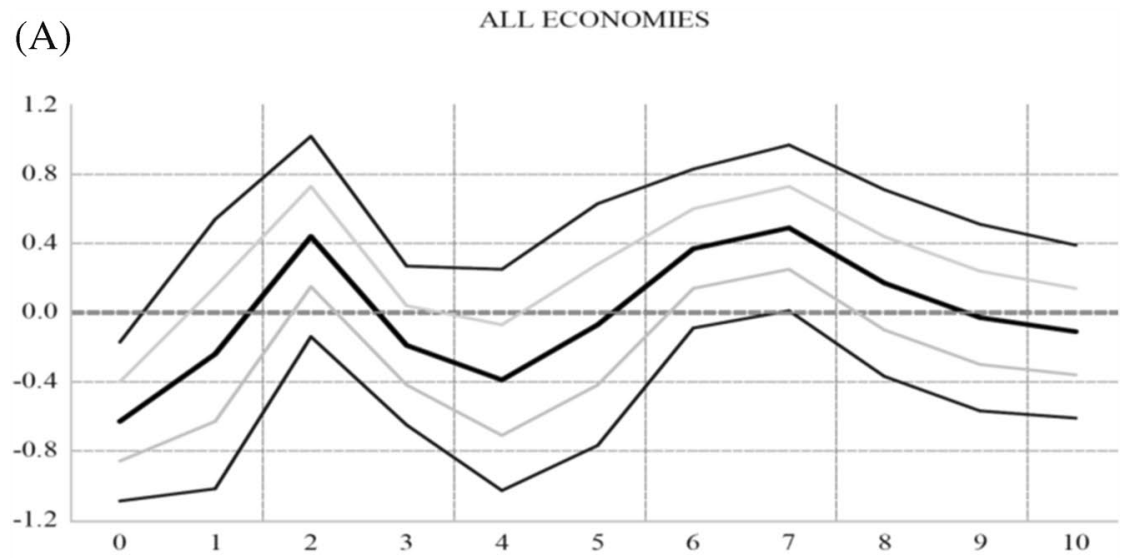

ALL COMBATTANTS

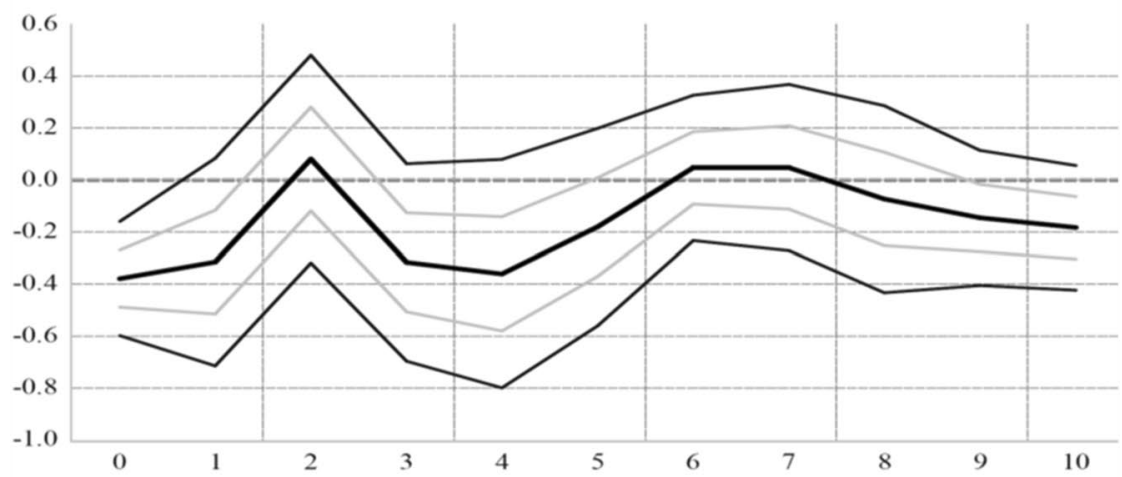

ALL NON-COMBATTANTS

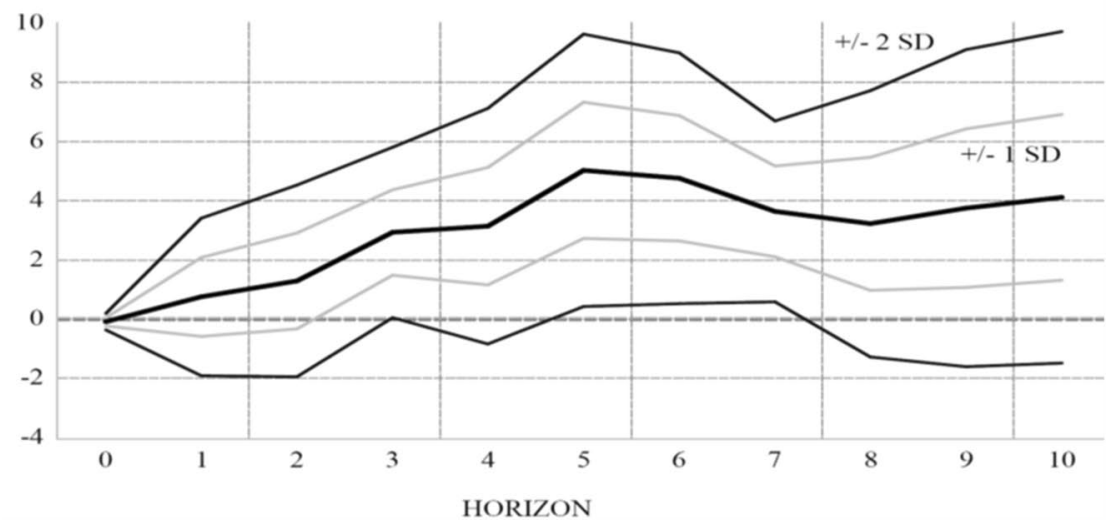




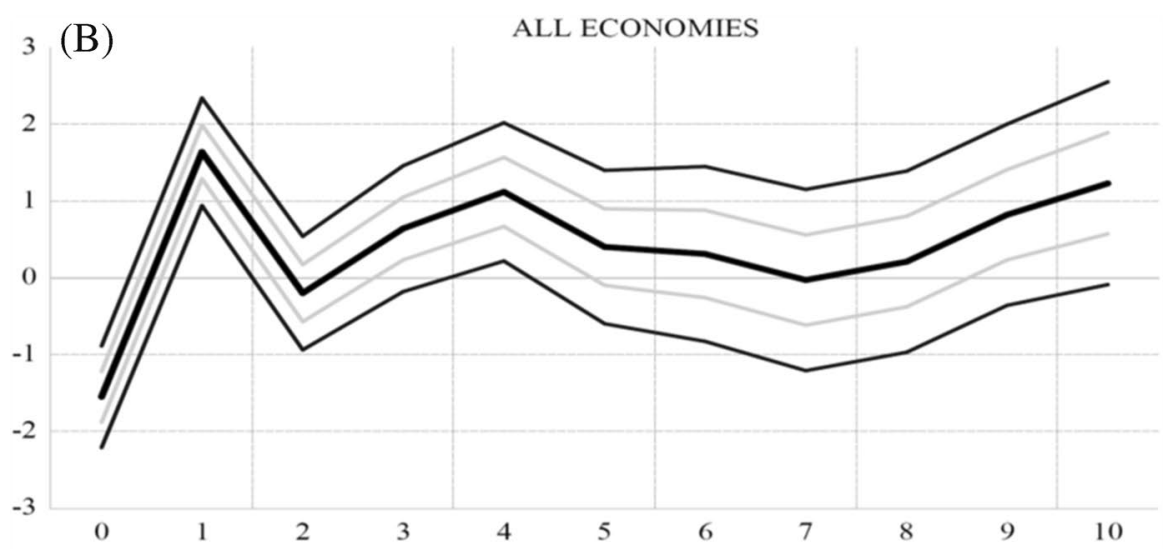

ALL COMBATTANTS

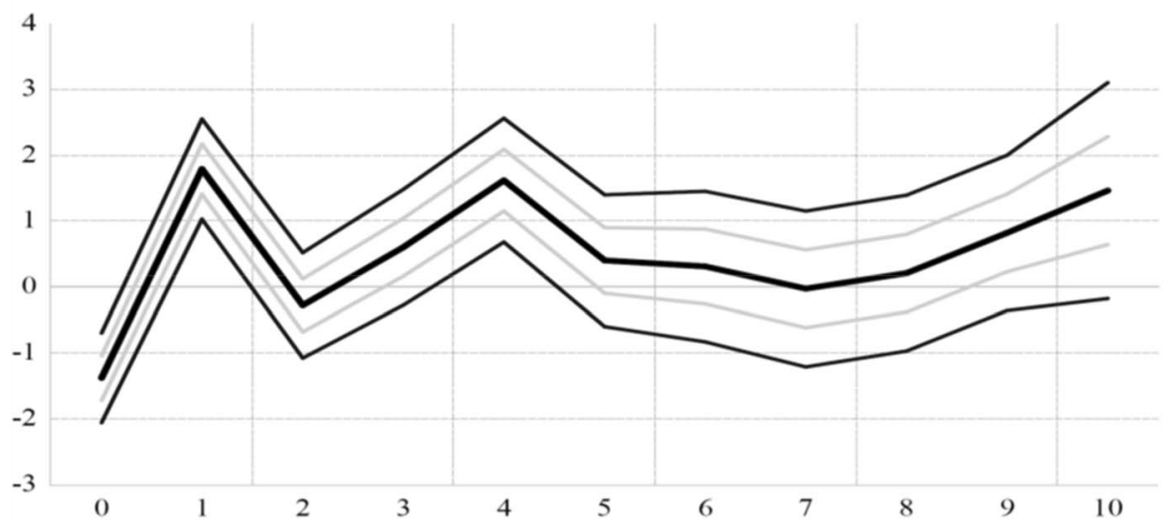

ALL NON-COMBATTANTS

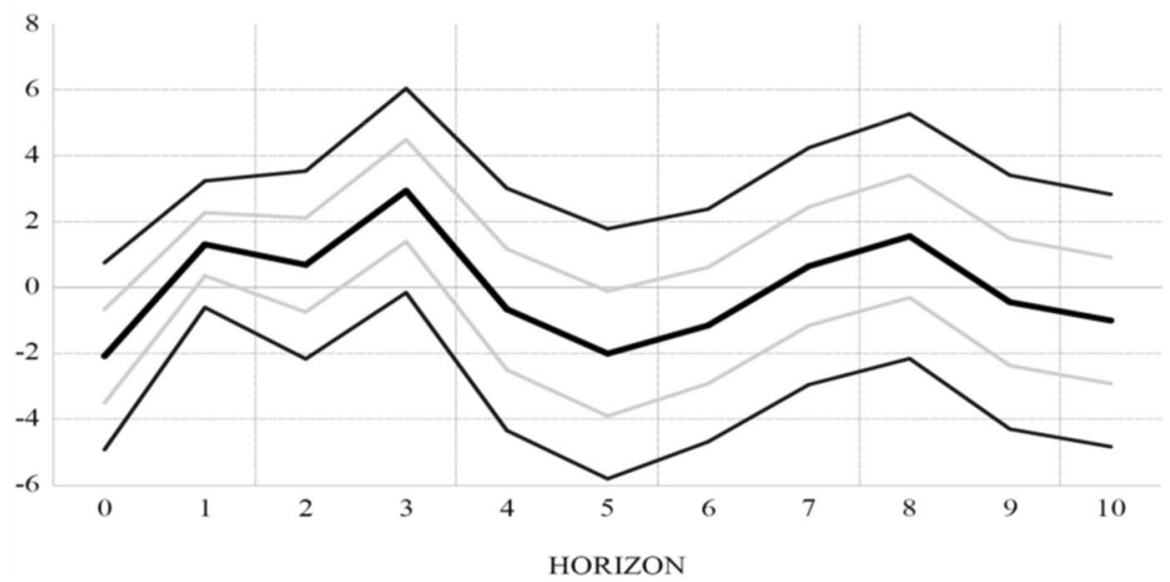

Fig. 3 (continued) 

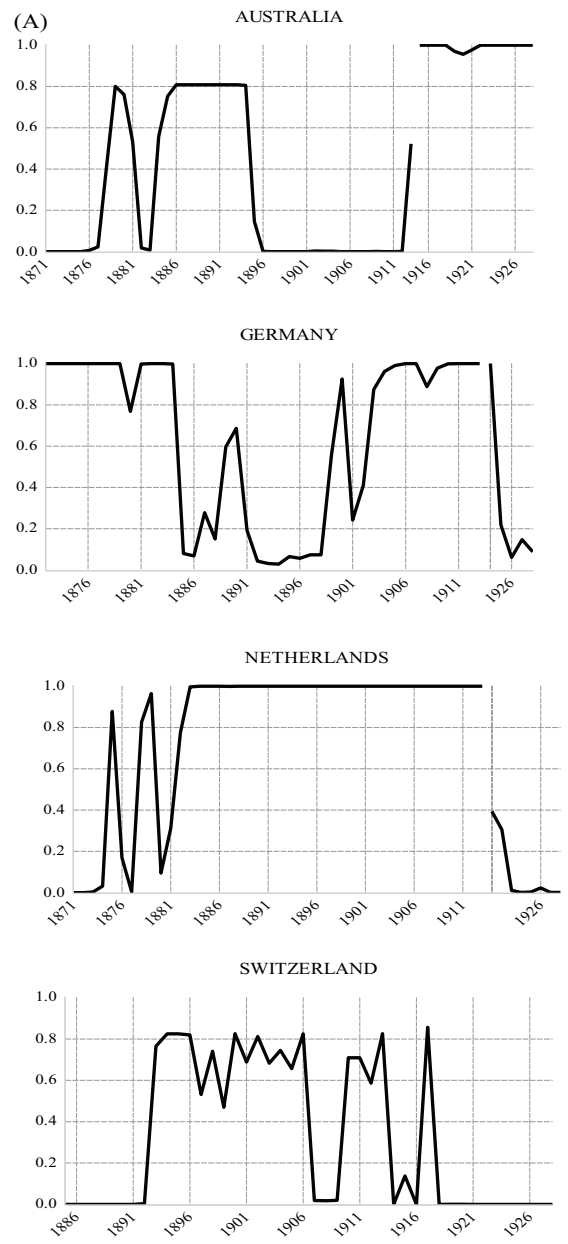

CANADA

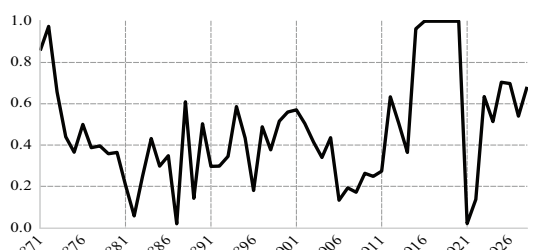

JAPAN

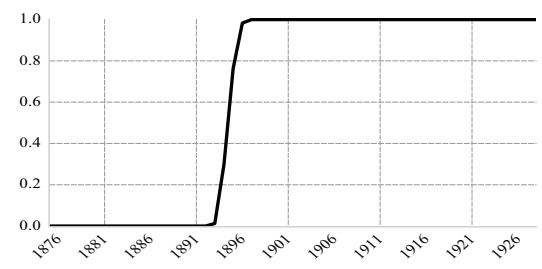

PORTUGAL
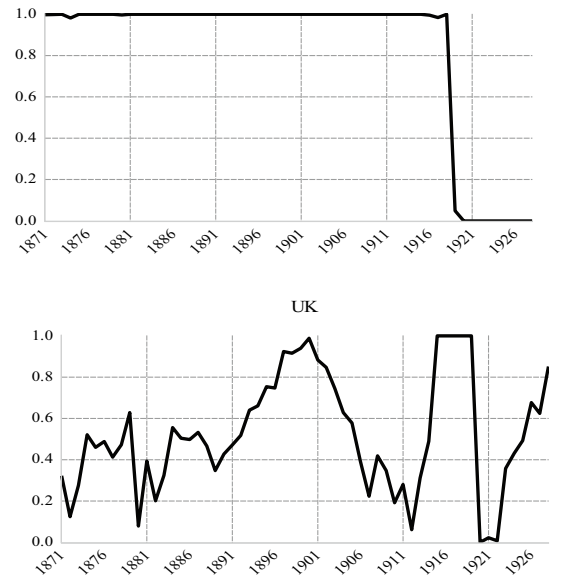

Fig. 4 A. Probability of Remaining in the Globalization State: Openness. Note: Eq. (1) estimates of being in the high probability state (high degree of openness) in a two-regime Markov switching model with openness or the real interest rate as a function of lagged inflation whose imnpact is regime-specific. In addtion, deaths and combat deaths, and UK openness, lagged one year, are added determinants common to both regimes. See the main text for more details. Selected estimates as explained in the text. Gaps due to missing data for some years for some countries. B. Probability of Remaining in the Financial Globalization State: Real Interest Rates. Note: Eq. (2). See text and notes to Fig. 4A

The forecasts for the combatant countries (top portion of Fig. 5) suggest quite clearly that the combined impact of the war and the pandemic generated some deglobalization since actual levels of openness are generally lower over time than what the model would have forecast based on pre-1914 data. A few countries, however, eventually recover after the pandemic ends (Canada, Germany, Italy, Portugal). Only Belgium sees actual levels of openness higher post-1913 than what the model forecasts. That said, the severity of the impact does vary across countries with Australia, Japan, and the UK experiencing the greatest divergence from what the pre-war 
(B)

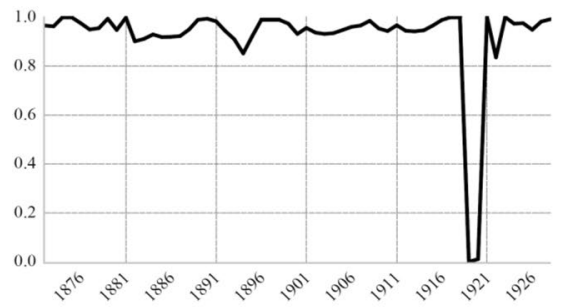

NORWAY

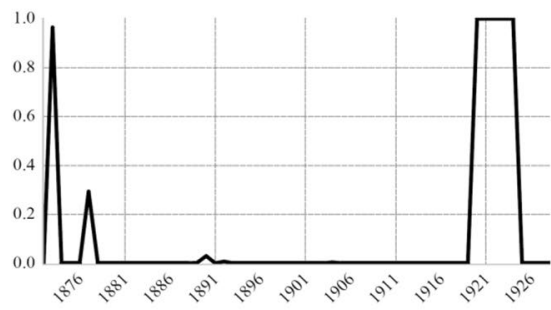

SPAIN

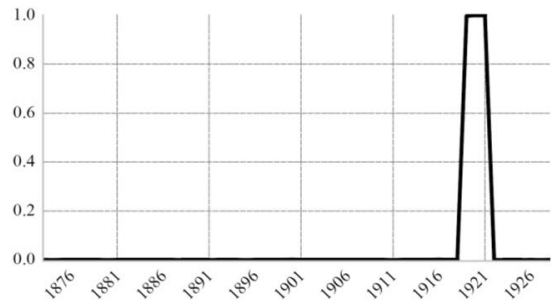

USA

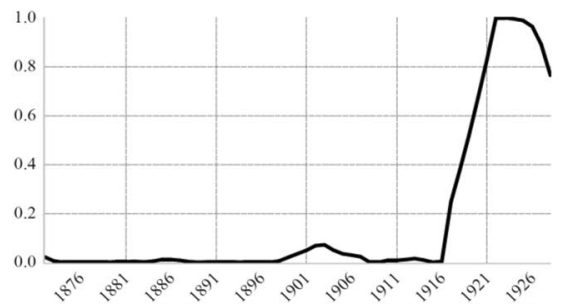

NETHERLANDS

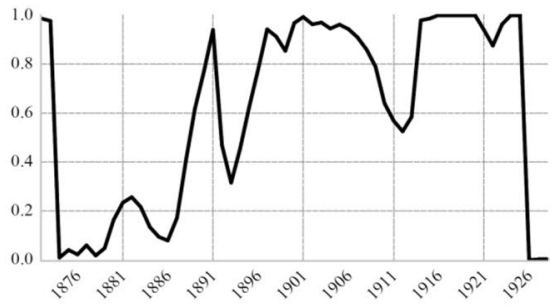

PORTUGAL

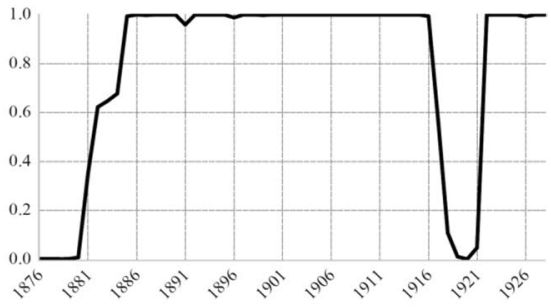

SWEDEN

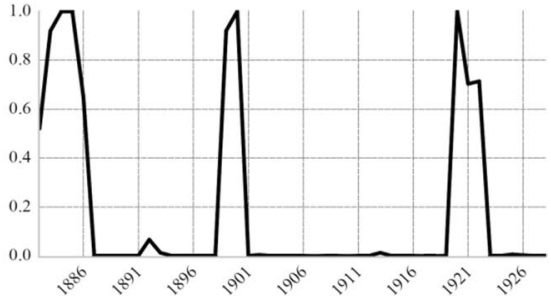

UK

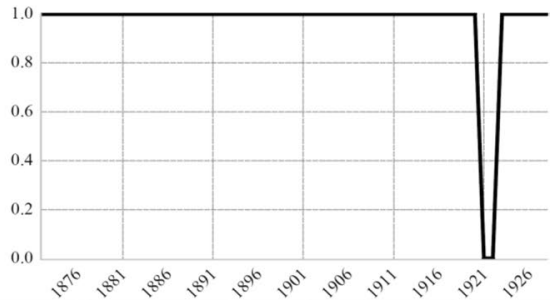

Fig. 4 (continued)

model would forecast while for France the negative impact is relatively modest. There is little overall impact on USA openness. When we consider the non-combatants countries it is striking how small the impact is of the war and the pandemic. The forecasts reinforce the combatant versus non-combatant distinction seen throughout the various statistical analyses performed above. Finally, as shown in Table 3, real interest rates forecasts yield mixed results for combatant countries with half of the forecasts lower than mean real interest rate levels for the full sample. In contrast, for non-combatant countries, mean observed real interest rates over the full sample are higher than the counterfactual forecasts and are lower only for Finland and the 


\section{(A) Combatant Countries}

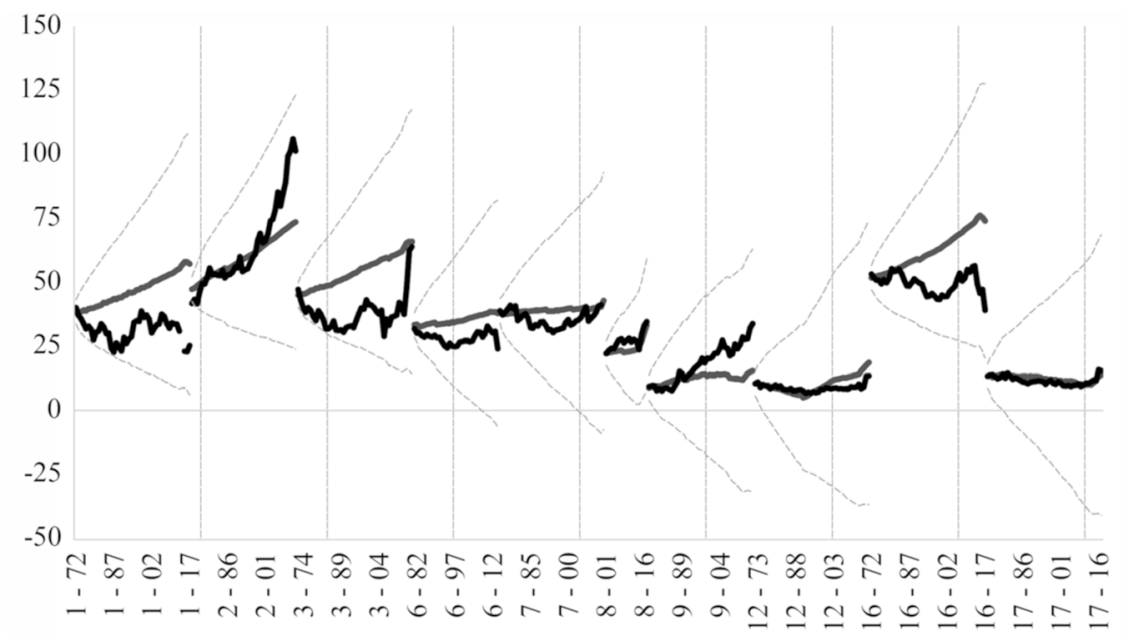

(B) Non-Combatant Countries

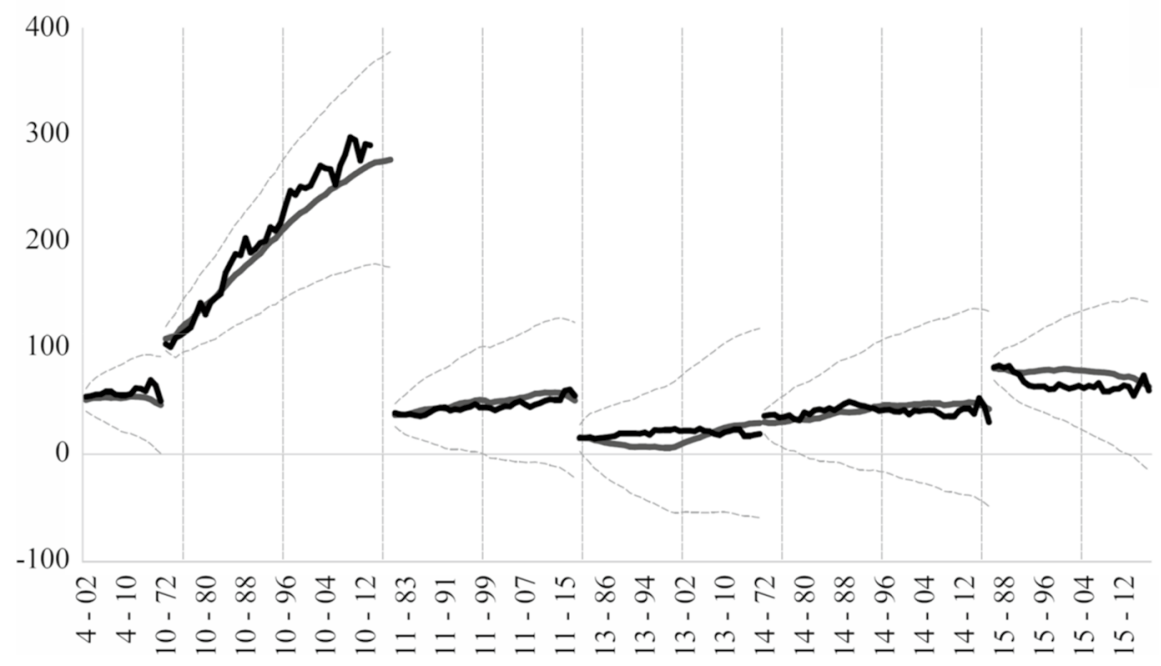

Fig. 5 Cross-Country Out of Sample Forecasts of Openness. A Combatant Countries. B Non-Combatant Countries. Note: The thick black line is observed $\omega$; the relatively smooth line is the (counterfactual) out of sample forecast (1870-1913) from Eq. (1). The dashed lines are \pm 2 SD confidence intervals. The horizontal axis is labelled country-year. For example, 1-17 is the (forecast) of openness for Australia in 1917. Country number key: $1=$ Australia, $2=$ Belgium, $3=$ Canada, $4=$ Denmark, $5=$ Finland, $6=$ France, $7=$ Germany, $8=$ Italy, $9=$ Japan, $10=$ Netherlands, $11=$ Norway, $12=$ Portugal, $13=$ Spain, $14=$ Swe den, $15=$ Switzerland, $16+\mathrm{UK}, 17=\mathrm{USA}$

Netherlands. The asymmetry between the two groups of countries is retained but, in just over half of the countries examined, the combined impact of World War I and the Great Influenza generated higher real returns than would otherwise have been 
Table 3 Out of Sample Forecasts and Outturns for Real Interest Rates

\begin{tabular}{lcll}
\hline Country & $\begin{array}{l}\text { Observed } \rho: \\
1870-1928(\%)\end{array}$ & $\begin{array}{l}\text { Mean Forecasts } \\
(\%): \text { Combatants }\end{array}$ & $\begin{array}{l}\text { Mean Forecasts } \\
(\%): \text { Non-Com- } \\
\text { batants }\end{array}$ \\
\hline AUS & 4.44 & 2.35 & NA \\
BEL & -3.36 & INS & NA \\
CAN & 3.87 & 2.34 & NA \\
DNK & 4.78 & NA & 2.39 \\
FIN & -5.06 & NA & -4.95 \\
FRA & -6.08 & INS & NA \\
DEU & -36.96 & 2.50 & NA \\
ITA & -1.67 & -0.23 & NA \\
JPN & 2.35 & 3.30 & NA \\
NED & 4.40 & NA & 5.43 \\
NOR & 5.48 & NA & 0.84 \\
PRT & -14.15 & -0.96 & NA \\
ESP & 3.48 & NA & 3.03 \\
SWE & 4.77 & NA & 0.74 \\
CHE & 5.85 & NA & 0.01 \\
GBR & 3.73 & 0.20 & NA \\
USA & 1.47 & 2.31 & NA \\
\hline
\end{tabular}

Note: Real interest rate is the long-term interest rate less current inflation. Forecasts are based on Eq. (2) applied to data for 18701913 which is then used to generate out of sample forecasts for the period 1914-28. NA means not applicable; INS means insufficient data to generate out of sample forecasts

expected. Whether this reflects the impact of the "Roaring $20 \mathrm{~s}$ " on the global economy is unclear but the events that dominated the first two decades of the twentieth century did have an impact on financial integration. ${ }^{26}$

\section{Conclusions}

In the face of a major shock, it is understandable to seek insights from the past. The ongoing COVID-19 crisis is no different. Extant research has sought to determine the real economic consequences of earlier pandemics for which reasonably good data exist. Generally, the impact is found to be on par with major financial crises, particularly ones that originate with large scale banking failures.

There has been less formal empirical work about whether earlier pandemics herald changes in the degree of trade or financial integration, that is, the state of globalization

\footnotetext{
${ }^{26}$ It is worth noting that real GDP growth is higher on average in 15 of 17 countries during the 19221928 period than in the 1901-1913 heyday of pre-war globalization. The rebound in 1920s growth is especially noticeable in many former combatant countries. In contrast, there is a sharp reduction in growth in the 1930-1938 period in 16 of 17 countries. Details are in the appendix.
} 
broadly defined. This paper revisits the fallout from the Great Influenza of 1918-20 in 17 countries, many but not all in Europe, and asks whether there is evidence of a reversal in an era otherwise notable for a steep rise in globalization in the run-up to a global conflict followed immediately by a pandemic. After drawing parallels as well as differences with the most recent experience with rising globalization, I rely on a series of tests in trying to pinpoint the impact of the Great Influenza on globalization a century ago. The heterogeneity in the progress towards greater global trade and financial integration in the first decade of the twentieth century is under-appreciated even if there are unmistakable signs that progress towards greater integration took place.

Overall, the series of statistical analyses lead to the conclusion that the pandemic did not permanently reverse the globalization though it was slowed down. The onset of the Great Depression of the 1930s, eventually followed by another global war, limits our ability to see into the future beyond 1928. However, combatant and non-combatant countries experienced significantly different outcomes post-World War I and the pandemic. Indeed, the two major events combined greatly slowed down the process of globalization that was underway at the time. By contrast, the non-combatant countries were far less impacted. Nevertheless, in the case of trade openness, several combatant and non-combatant bounced-back after World War I and the pandemic while real interest rate divergences between these two groups appear to have grown after 1920. The large and volatile capital flows during this era, documented for example by Accominotti and Eichengreen (2016) leading to the collapse in the 1930s (also see Bordo et al. 2010) may also have played a role though again mainly for the non-combatants in the data set.

It is, of course, hazardous to rely too heavily on the era of the Great Influenza to predict the consequences for trade and financial integration once the COVID-19 has been overcome. Nevertheless, echoes from the past do ring true today. Feis (1925, pg. 164), writing during the "Roaring Twenties" from the US perspective, states: "One added national preoccupation dominates all others - the suddenly great importance and difficulty of our international economic relations."

It is worth reminding readers once again that the current state of the world is not comparable to the one a century ago notwithstanding the parallels previously discussed. Nevertheless, if there is one useful lesson, it is that integration will remain a force among certain blocs of countries while others may well choose to diverge. In 1918-20 the bloc consisted of combatants and non-combatants. If the foregoing prediction holds in future the blocs to be formed may well be along quite different lines, perhaps between populist leaning and non-populist leaning countries.

Supplementary Information The online version contains supplementary material available at https://doi. org/10.1007/s10368-021-00526-1.

\section{References}

Ahamed L (2009) The Lords of Finance: The Bankers Who Broke the World. The Penguin Press, New York

Ansant S, Pelat C, Boelle P-Y, F, Carrat, A. Flahault, and A-J. Vallerin, (2009) Mortality Burden of the 1918-1919 Influenza Pandemic in Europe. Influenza Other Respir Viruses 3:99-106 
Antràs P, Redding SJ, Rossi-Hansberg E (2020) "Globalization and Pandemics", NBER working paper 27840, September

Accominotti O, Eichengreen B (2016) The Mother of all Sudden Stops: Capital Flows and Reversals in Europe, 1919-32. Econ Hist Rev 69(2):469-492

Avery C, Bossert W, Clark A, Ellison G, Ellison SF (2020) An Economist's Guide to Epidemiology Models of Infectious Diseases. Journal of Economic Perspectives 34(Fall):79-104

Bairoch P (1982) International industrialization levels from 1750 to 1980. Journal of European History 2:269-333

Baldwin R (2009) "The Great Trade Collapse: What Caused It and What Does It Mean", VOXeu, 27 November, https://voxeu.org/article/great-trade-collapse-what-caused-it-and-what-does-it-mean

Baldwin R, Martin P (1999) “Two Waves of Globalization: Superficial Similarities, Fundamental Differences", NBER working paper 6904, January

Barro R (2020) "Non-Pharmaceutical Interventions and Mortality in U.S. Cities During the Great Influenza Pandemic, 1918-1919”, NBER working paper 27049, April.

Barro R, Ursúa RJ, Weng J (2020) “The Coronavirus and the Great Influenza Pandemic: Lessons from the 'Spanish Flu' for the Coronavirus' Potential Effects on Mortality and Economic Activity", NBER working paper 26866, April

Barry J (2004) The Great Influenza. Viking, New York

Bishop J (2020) "Economic Effects of the Spanish Flu”, Reserve Bank of Australia Bulletin, June

Blanchard O (2017) "Currency Wars, Coordination, and Capital Controls", International Journal of Central Banking (June): 283-308, available from https://www.ijcb.org/journal/ijcb17q2a8.pdf

Bordo M, Cavallo A, Meissner C (2010) Sudden Stops: Determinants and Output Effects in the First Era of Globalization, 1880-1913. J Dev Econ 91:227-241

Bordo M, Eichengreen B, Irwin D (1999) Collins, Susan and Robert Lawrence (eds.) Brookings Trade Policy Forum. Washington, DC: Brookings Institution, 1999

Bordo M, Kydland F (1995) The Gold Standard as a Rule: An Essay in Exploration. Explor Econ Hist 32(October):423-464

Bordo M, Siklos PL (2016) Central bank credibility: an historical and quantitative exploration. In Bordo M, Eitrheim O, Flandreau M (eds) Central Banks At A Crossroads. Cambridge University Press, Cambridge, pp 62-144

Burdekin R (2021) Death and the Stock Market: International Evidence from the Spanish Flu. Appl Econ Lett $1: 9$

Burdekin R (2020) Economic and Financial Effects of the 1918-19 Spanish Flu Epidemic. Journal of Infectious Diseases and Therapy 8(6):1000439

Burdekin R, Siklos PL (2004) Deflation: current and historical perspectives. Cambridge University Press, Cambridge

Candela R, Geloso V (2021) Economic Freedom, Pandemics, and Robust Political Economy. South Econ J 87(4):1250-1266

Carter Z (2020) The Price of Peace: Money, Democracy, and the Life of John Maynard Keynes. Random House, New York

Cooke D (2010) Openness and inflation. Journal of Money, Credit and Banking 42(March-April):267-287

Copley S, Edgar P (1993) David Hume: selected essays. Oxford University Press, Oxford and New York

Crafts N, Venables A (2003) "Globalization in History: A Geographic Perspective", in in M. Bordo, A. Taylor, and J. Williamson (Editors), Globalization in Historical Perspective (Chicago: University of Chicago Press), pp. 323-364

Darwin J (2020) Unlocking the World. Allen Lane, London

De Santis R, Van der Vehen W (2020) "Macroeconomic Risks Across the Globe Die to the Spanish Flu", European Central bank working paper 2466, September

Dreher A (2006) Does Globalization Affect Growth? Evidence from a new Index of Globalization. Appl Econ 38(10):1091-1110

Economist The (2020) "Only the World Wars Have Rivalled Covod-19 for News Coverage", 19 December

Eichengreen B (1992) Golden Fetters: The Gold Standard and the Great Depression, 1919-39. Oxford University Press, Oxford

Eichengreen B, Leblang D (2008) Democracy and Globalization. Econ Politics 20(November):289-334 
Eichengreen B, Bordo M (2003) "Crises Now and Then: What Lessons from the Last Era of Financial Globalization?" in P. Mizen (ed.), Monetary History, Exchange Rates and Financial Markets: Essays in Honor of Charles Goodhart, Cheltenham: Edward Elgar, vol. 2, pp.52-91

Feis H (1925) "Changing America Has New Economic Problems", New York Times, 27 December

Ferguson N (2020) "Black Swans, Gragon Kings, and Gray Rhinos: The World War of 1914-1918 and the Pandemic of 2020-?", History working paper 2020-1, May, Hoover Institution, Stanford University

Field AJ (2011) A Great Leap Forward: 1930s Depression and US Economic Growth (New Haven, CT.: Yale University Press)

Flandreau M, Zumer F (2004) “The Making of Global Finance 1880-1913”, OECD Development Centre Studies

Garrett T (2007) "Economic Effects of the 1918 Influenza Pandemic: Implications for a Modern-Day Pandemic", Federal Reserve Bank of St. Louis, October, available from https:/www.stlouisfed.org/ /media/files/pdfs/community-development/research-reports/pandemic_flu_report.pdf

Geloso V, Bologna Pavlik J (2021) Economic Freedom and the Economic Consequencs of the 1918 Pandemic. Contemp Econ Policy 39(2):255-263

Geloso, V., and I. Murtavashvili (2020), "Pandemics, Economic Freedom, and Institutional Trade-Offs", European Journal of Law and Economics (forthcoming).

Gordon RJ (2017) The Rise and Fall of American growth: The US Standard of Living since the Civil War. Princeton University Press, Princeton, N.J.

Gygli S, Haelg F, Potrafke N, J.-E. Sturm, (2019) The KOF Globalisation Index - Revisited. Review of International Organizations 14(3):543-574. https://doi.org/10.1007/s11558-019-09344-2

Guimbeau A, Menon N, Musacchio A (2020) "The Brazilian Bombshell? The Long-Term Impact of the 1918 Influenza Pandemic the South American Way”, NBER working paper 26929, April

Humphries M (2012) The Last Plague: Spanish Influenza and the Politics of Health in Canada (Toronto, ON: University of Toronto Press)

Jordà, O., S. Singh, and A. Taylor (2020), Longer Run Economic Consequences of Pandemics", NBER working paper 26934, April.

Jordà O (2005) "Estimation and Inference of Impulse responses by Local Projections. American Economic Review 95(1):161-182

Karlsson M, Nilsson T, Pichler S (2014) The Impact of the 1918 Spanish Flu on Economic Performance in Sweden: An Investigation into the Consequences of an Extraordinary Mortality Shock. J Health Econ 36:1-19

Kermack W, McKendrick AG (1927) A Contribution to the Mathematical Theory of Epidemics. Proceedings of the Royal Society of London A 115(772):700-721

Keynes JM (1919) The Economic Consequences of the Peace. Macmillan, London

Kydland F, Prescott E (1977) Rules Rather than Discretion: The Inconsistency of Optimal Plans. J Polit Econ 65(3):473-491

Ma C, Rogers J, Zhou S (2020) "Modern Pandemics: Recession and Recovery", International Finance Discussion Paper 1295, August

Macmillan M (2001) Paris 1919: Six Months That Changed the World. Random House, New York

Marshall M, Gurr T (2020) Polity5: Political Regime Characteristics and Transition, 1800-2018 Center for Systemic Peace, April, available from http://www.systemicpeace.org/inscr/p5manualv2018.pdf

Michie R (1992) The City of London: Continuity and Change. Macmillan, London

Mitchell BR (1992) International Historical Statistics: Europe, 1750-1988, 3rd edn. Stockton Press, New York

Mitchener K, Shizume M, Weidenmeier M (2010) Why Did Countries Adopt the Gold Standard? Lessons from Japan. J Econ Hist 70(March):27-56

Neal L, Weidenmeier M (2003) Crises in the Global Economy: From Tulips to Today. In: Bordo M, Taylor A, Williamson J (eds) Globalization in Historical Perspective. University of Chicago Press, Chicago, pp 473-510

Obstfeld M, Taylor A (2003) Globalization and Capital Markets. In: Bordo M, Taylor A, Williamson J (eds) Globalization in Historical Perspective. University of Chicago Press, Chicago, pp 121-183

O'Rourke K (2019) Economic History and Contemporary Challenges to Globalization. Journal of Economic History 79(June):356-382

Prados de la Escosura L (2016) Economic Freedom in the Long-Run: Evidence from OECD Countries. Econ Hist Rev 69(2):435-468 
Quinn W, Turner J (2020) "Boom and Bust: A Global History of Financial Bubbles" (Cambridge, U.K.: Cambridge University Press)

Rodrik D (2020a) "Why Does Globalization Fuel Populism? Economics, Culture, and the Rise of RightWing Populism", working paper, September. Annual Review of Economics (forthcoming).

Rodrik D (2020b) "Globalization in the 'New Normal", Distinguished ECFIN Lecture, November

Romer D (1993) Openness and Inflation: Theory and Evidence. Quart J Econ 108(November):869-903

Schularick M, Steger T (2006) "Does Financial Integration Spur Economic Growth? New Evidence from the First Era of Globalization", CESifo working paper 1691, March

Schularick M, Solomou S (2011) Tariffs and Economic Growth in the First Era of Globalization. J Econ Growth 16:33-70

Shiller R (2020) “Why We Can't Foresee the Pandemic's Long-Term Effects”, New York Times, 29 May

Shizume M (2009) "The Japanese Economy During the Interwar Period: Instability in the Financial System and the Impact of the World Depression", Bank of Japan Review, May

Spreeuwenberg P, Kroneman M, Paget J (2018) Reassessing the Glonbal Mortality Burden of the 1918 Influenza Pandemic. Am J Epidemiol 187(12):2561-2567

Staley, E. (1971), World Economy in Transition (Port Washington, N.Y.: Kennikat Press).

Terra C (1998) Openness and inflation: a new assessment. Quarterly Journal of Economics 113(May):641-648

Tooze A (2014) The Deluge: The Great War, America and the Remaking of the Global Order, 19161931. Penguin books, New York

Velde FR (2020) "What Happened to the US Economy During the 1918 Influenza Pandemic? A View Through High-Frequency Data", Federal Reserve Bank of Chicago Working Paper 2020-11

Wynne M, Kersting E (2007) Openness and inflation. Federal Reserve Bank of Dallas Staff Papers No. 2, April

Publisher's note Springer Nature remains neutral with regard to jurisdictional claims in published maps and institutional affiliations. 